ARTICLE

https://doi.org/10.1038/s41467-018-08144-3

\title{
Chromium-ruthenium oxide solid solution electrocatalyst for highly efficient oxygen evolution reaction in acidic media
}

Yichao Lin ${ }^{1,2}$, Ziqi Tian ${ }^{1,2}$, Linjuan Zhang ${ }^{3}$, Jingyuan Ma ${ }^{4}$, Zheng Jiang $\mathbb{D}^{4}$, Benjamin J. Deibert ${ }^{5}$, Ruixiang Ge ${ }^{1,2} \&$ Liang Chen ${ }^{1,2}$

The development of active, acid-stable and low-cost electrocatalysts for oxygen evolution reaction is urgent and challenging. Herein we report an Iridium-free and low rutheniumcontent oxide material $\left(\mathrm{Cr}_{0.6} \mathrm{Ru}_{0.4} \mathrm{O}_{2}\right)$ derived from metal-organic framework with remarkable oxygen evolution reaction performance in acidic condition. It shows a record low overpotential of $178 \mathrm{mV}$ at $10 \mathrm{~mA} \mathrm{~cm}{ }^{-2}$ and maintains the excellent performance throughout the $10 \mathrm{~h}$ chronopotentiometry test at a constant current of $10 \mathrm{~mA} \mathrm{~cm}{ }^{-2}$ in $0.5 \mathrm{M} \mathrm{H}_{2} \mathrm{SO}_{4}$ solution. Density functional theory calculations further revealed the intrinsic mechanism for the exceptional oxygen evolution reaction performance, highlighting the influence of chromium promoter on the enhancement in both activity and stability.

\footnotetext{
${ }^{1}$ Ningbo Institute of Materials Technology and Engineering, Chinese Academy of Sciences, 315201 Ningbo, Zhejiang, China. ${ }^{2}$ University of Chinese Academy of Sciences, 100049 Beijing, China. ${ }^{3}$ Shanghai Institute of Applied Physics, Chinese Academy of Sciences, 201800 Shanghai, China. ${ }^{4}$ Shanghai Synchrotron Radiation Facility, Shanghai Institute of Applied Physics, Chinese Academy of Sciences, 201204 Shanghai, China. ${ }^{5}$ Department of Chemistry and Chemical Biology, Rutgers, The State University of New Jersey, Piscataway, NJ 08854, USA. These authors contributed equally: Yichao Lin, Ziqi Tian. Correspondence and requests for materials should be addressed to L.C. (email: chenliang@nimte.ac.cn)
} 
O xygen evolution reaction (OER) or the water oxidation plays a key role in clean energy technologies, including hydrogen production through water electrolysis, electrochemical or photoelectrochemical $\mathrm{CO}_{2}$ reduction and reversible fuel cells for production of clean electricity ${ }^{1-3}$. Essentially, the process of OER is a four electron and four proton coupled electrochemical reaction, demanding a higher energy (i.e., higher overpotential) to overcome the kinetic barrier than the hydrogen evolution reaction (HER), which is a two electron-transfer reaction. In the past decades, substantial research effort has been devoted to the design and development of OER electrocatalysts with enhanced electrode kinetics and stability. To date, various OER catalysts, such as transition metal oxides ${ }^{4-6}$, perovskite ${ }^{7,8}$, and layered structure materials ${ }^{9,10}$, have been reported. However, these OER electrocatalysts still suffer from sluggish kinetics and/or low stability in acidic media. Compared with alkaline conditions, OER catalysis under acidic conditions is much more preferable because acidic electrolyte has higher ionic conductivity and fewer unfavorable reactions $s^{11,12}$. In addition, commercially available water electrolysis assemblies use cation exchange membrane, e.g., Nafion, as the ionic conductor, which requires OER to be operated in acidic environment. Unfortunately, most of the known active metal oxides cannot survive under harsh acidic operating conditions. Currently, rutile-structured ruthenium $(\mathrm{Ru})$ and iridium (Ir) oxides are the two best catalysts for OER in acidic media ${ }^{13-15}$. It is widely accepted that $\mathrm{RuO}_{2}$ has higher activity but lower stability than $\mathrm{IrO}_{2}{ }^{16-18}$. Thus, to develop OER catalysts with both high activity and stability, the use of mixed phase or solid solution of $\mathrm{RuO}_{2}$ and $\mathrm{IrO}_{2}$ has been investigated $^{19-22}$. Very recently, three new types of Ir-based double perovskites ${ }^{23}$, multiphase $\mathrm{IrNiO}_{\mathrm{x}}$ or $\mathrm{IrO}_{\mathrm{x}} / \mathrm{SrIrO}_{3}{ }^{24,25}$, and pyrochlores-structured Ir-based oxides ${ }^{26}$, were reported to be active and relatively stable toward OER in acidic media. However, we note that little attention has been paid to design cheaper Ru-based electrocatalysts, particularly with low $\mathrm{Ru}$ content, for OER in acidic condition ${ }^{27}$. Indeed, it is desirable to modulate the electronic structure by replacing part of Ru with suitable transition metals in order to improve the OER activity. Furthermore, the replacement by cheaper transition metal is also advantageous in terms of cost.

Metal-organic frameworks (MOFs), a unique type of porous materials with ultrahigh porosity, tunable pore sizes and morphology, and well-characterized crystalline architectures, have emerged as excellent templates or platforms for preparing electrocatalysts with high performance, such as $\mathrm{N}$-doped porous carbon, metal oxide nanocomposites ${ }^{3,28}$. In light of these successful studies, we propose to design Ru-based electrocatalysts based on MOF templates, which can make use of the porosity to load $\mathrm{Ru}$ sources and the original metal node as promoter. Herein, we present a low-cost Ir-free rutilestructured chromium-ruthenium oxide electrocatalyst (i.e., $\mathrm{Cr}_{0.6} \mathrm{Ru}_{0.4} \mathrm{O}_{2}$ ) derived from MIL-101 (Cr) which exhibits record low overpotential and high stability toward OER in acidic media. We chose MIL-101 (Cr) because of its ultra-high surface area (above $3000 \mathrm{~m}^{2} \mathrm{~g}^{-1}$ ) and large pore sizes $(2.9-3.2 \mathrm{~nm})$ that can facilitate the loading of $\mathrm{Ru}$ precursors ${ }^{29}$. Moreover, density functional theory (DFT) calculations suggested that $\mathrm{Cr}$ plays a critical role in improving the stability and OER activity by tuning the electronic structure of $\mathrm{RuO}_{2}$ phase. The resulting $\mathrm{Cr}_{0.6} \mathrm{Ru}_{0.4} \mathrm{O}_{2}$ electrocatalyst exhibits an overpotential of $178 \mathrm{mV}$ at $10 \mathrm{~mA} \mathrm{~cm}^{-2}$, a small Tafel slope $\left(58 \mathrm{mV} \mathrm{dec}^{-1}\right)$, and stable chronopotentiometric performance under $10 \mathrm{~mA} \mathrm{~cm}^{-2}$ in 0.5 $\mathrm{M} \mathrm{H}_{2} \mathrm{SO}_{4}$ solution for $10 \mathrm{~h}$, which outperforms the most active OER electrocatalysts reported to date, such as $\mathrm{BaYIrO}_{6}{ }^{23}, \mathrm{IrO}_{\mathrm{x}} /$ $\mathrm{SrIrO}_{3}{ }^{25}$, and $\mathrm{Y}_{2} \mathrm{Ru}_{2} \mathrm{O}_{7-\delta}{ }^{27}$.

\section{Results}

Preparation and characterization of $\mathrm{RuCl}_{3}-\mathrm{MIL}-101(\mathrm{Cr})$ and $\mathbf{C r}_{\mathbf{0 . 6}} \mathbf{R u}_{\mathbf{0 . 4}} \mathbf{O}_{2}$. The route to the preparation of $\mathrm{RuCl}_{3}-\mathrm{MIL}-101$ (Cr) precursor and $\mathrm{Cr}_{0.6} \mathrm{Ru}_{0.4} \mathrm{O}_{2}$ powders is illustrated in Fig. 1. $\mathrm{RuCl}_{3}$ was firstly loaded into the pores of MIL-101 (Cr) by means of impregnation. After loading $\mathrm{RuCl}_{3}$, the color of MIL-101 (Cr) changed from light green to brown (the color of $\mathrm{RuCl}_{3}$ ) (Supplementary Figure 1), visually indicating the successful loading of $\mathrm{RuCl}_{3}$. The resulting $\mathrm{RuCl}_{3}-\mathrm{MIL}-101$ (Cr) composite was further annealed under air at temperatures between 450 and $600{ }^{\circ} \mathrm{C}$ for 4 $\mathrm{h}$ to fabricate $\mathrm{Cr}_{0.6} \mathrm{Ru}_{0.4} \mathrm{O}_{2}$ powders. $\mathrm{RuCl}_{3}-\mathrm{MIL}-101$ (Cr) was characterized using a combination of power X-ray diffractions (PXRD), scanning electron microscopy (SEM), inductively coupled plasma-mass spectroscopy (ICP-MS) and $\mathrm{N}_{2}$ adsorption/ desorption measurements at $77 \mathrm{~K}$. As shown in Fig. 2a. PXRD pattern of the resulting $\mathrm{RuCl}_{3}$-MIL-101 (Cr) was essentially identical to that of original MIL-101 (Cr), suggesting that the crystalline structure of MIL-101 (Cr) was preserved after loading $\mathrm{RuCl}_{3}$. The reduced intensity of the peaks below $7^{\circ}$ after loading $\mathrm{RuCl}_{3}$ can be attributed to the pore filling of MIL-101 (Cr), which has also been observed in PEI incorporated MIL-101 $(\mathrm{Cr})^{30}$. There was no peak for $\mathrm{RuCl}_{3}$, indicating that $\mathrm{RuCl}_{3}$ did not crystalize in the pores of MIL-101 (Cr) but was adsorbed on the pore surface. SEM characterization was conducted to analyze the morphology of MIL-101 (Cr) before and after loading $\mathrm{RuCl}_{3}$. As displayed in Fig. 2b, MIL-101 (Cr) has an octahedral morphology with small particle size $(\sim 100 \mathrm{~nm})$, which can effectively facilitate the diffusion of $\mathrm{RuCl}_{3}$ into MIL-101 (Cr) pores. After loading $\mathrm{RuCl}_{3}$, morphology change of MIL-101 (Cr) was not observed. ICP-MS was employed to evaluate the loading amount of $\mathrm{RuCl}_{3}$ in MIL-101 (Cr). The measured atomic ratio of $\mathrm{Cr} / \mathrm{Ru}$ was $6: 4$, corresponding to $37.8 \mathrm{wt} \% \mathrm{RuCl}_{3}$ content in $\mathrm{RuCl}_{3}-\mathrm{MIL}-101$ (Cr). $\mathrm{N}_{2}$ adsorption/desorption measurements of MIL-101 (Cr) and $\mathrm{RuCl}_{3}$-MIL-101 (Cr) were further conducted to evaluate their surface area and pore volume (Supplementary Figure 2). MIL-101 (Cr) exhibited a saturated $\mathrm{N}_{2}$ uptake of $1050 \mathrm{~cm}^{3} \mathrm{~g}^{-1}$, which was consistent with values reported in literatures ${ }^{31,32}$. The corresponding pore volume and BET surface area were calculated to be $1.63 \mathrm{~cm}^{3} \mathrm{~g}^{-1}$ and $3373 \mathrm{~m}^{2} \mathrm{~g}^{-1}$, respectively. Upon the loading of $\mathrm{RuCl}_{3}$, the pore volume and Brunauer-Emmett-Teller (BET) surface area were decreased to $0.97 \mathrm{~cm}^{3} \mathrm{~g}^{-1}$ and $1783 \mathrm{~m}^{2} \mathrm{~g}^{-1}$, respectively.

Fine powders with the composition of $\mathrm{Cr}_{0.6} \mathrm{Ru}_{0.4} \mathrm{O}_{2}$ were obtained by annealing $\mathrm{RuCl}_{3}$-MIL-101 (Cr) under air for $4 \mathrm{~h}$ at a series of temperatures between 400 and $650{ }^{\circ} \mathrm{C}$, denoted as $\mathrm{Cr}_{0.6} \mathrm{Ru}_{0.4} \mathrm{O}_{2}$ ( $\mathrm{T}, \mathrm{T}$ is the annealing temperature). As shown in the PXRD patterns (Fig. 2c), the increased intensity of peaks with annealing temperature indicates that the higher annealing temperature can lead to better cystallinity of $\mathrm{Cr}_{0.6} \mathrm{Ru}_{0.4} \mathrm{O}_{2}$. When the annealing temperature was lower than $450{ }^{\circ} \mathrm{C}$, very poor crystalline samples were formed. The PXRD patterns of $\mathrm{Cr}_{0.6} \mathrm{Ru}_{0.4} \mathrm{O}_{2}$ powders annealed above $500^{\circ} \mathrm{C}$ are essentially identical, and can be indexed as a solid solution of rutile $\mathrm{CrO}_{2}$ and $\mathrm{RuO}_{2}$ with tetragonal system and $\mathrm{P} 42 / \mathrm{mnm}$ space group (the refined lattice parameters are listed in Supplementary Table 1 and the standard PXRD patterns of $\mathrm{CrO}_{2}$ and $\mathrm{RuO}_{2}$ were shown in Supplementary Figure $3 \mathrm{a}$ for comparison). The structure of $\mathrm{Cr}_{0.6} \mathrm{Ru}_{0.4} \mathrm{O}_{2}$ is refined by Rietveld refinement (Supplementary Figure $3 \mathrm{~b}$ ). As shown in Fig. $2 \mathrm{~d}, \mathrm{Cr}$ and $\mathrm{Ru}$ atoms are randomly distributed in the metal sites of the $\mathrm{Cr}_{0.6} \mathrm{Ru}_{0.4} \mathrm{O}_{2}$ lattice. These metal atoms are edge-sharing and octahedrally coordinated to form chains along the $\left[\begin{array}{lll}0 & 0 & 1\end{array}\right]$ direction. Each chain is connected to four neighboring chains by shared corners. The $\mathrm{MO}_{6}$ octahedra are tetragonally distorted, thus these $\mathrm{M}-\mathrm{O}$ bond distances are not equal. SEM images show that the morphologies of $\mathrm{Cr}_{0.6} \mathrm{Ru}_{0.4} \mathrm{O}_{2}$ powders became smaller, and their surface became much rougher 
after annealing (Fig. 3a and Supplementary Figure 4). Transmission electron microscopy (TEM) images indicate that the individual particles are composed of much smaller nanocrystals $(\sim 15 \mathrm{~nm})$ (Fig. 3b-d, Supplementary Figures 5-8). High resolution TEM (HR-TEM) image (Fig. 3e) and the corresponding fast Fourier transform (FFT, Fig. 3f) indicate that these nanocrystals are single-crystalline. Between these nanocrystals in a single $\mathrm{Cr}_{0.6} \mathrm{Ru}_{0.4} \mathrm{O}_{2}$ particle, many mesopores exist, facilitating the mass transfer in the OER process. The $\mathrm{N}_{2}$ adsorption/desorption

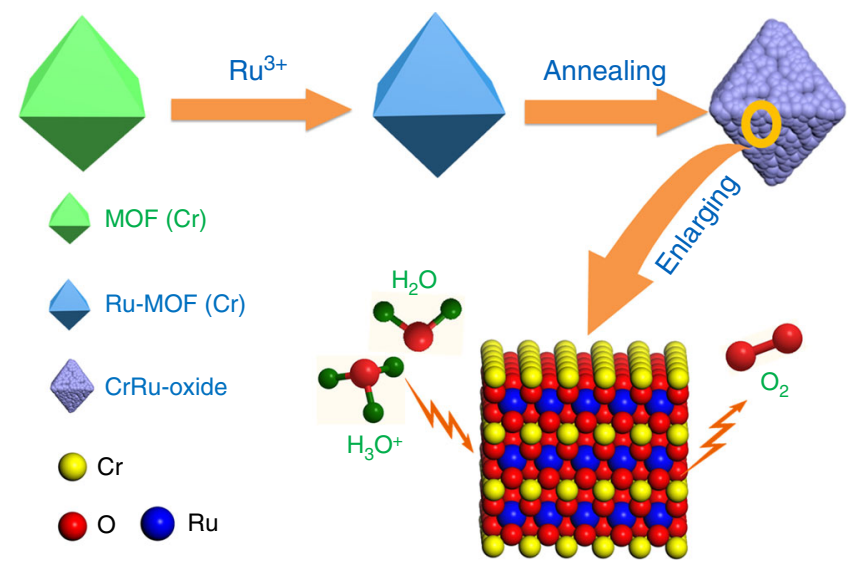

Fig. 1 Schematic illustration of the preparation of $\mathrm{Cr}_{0.6} \mathrm{Ru}_{0.4} \mathrm{O}_{2}$ electrocatalysts for OER application in acid media isotherms further confirm that $\mathrm{Cr}_{0.6} \mathrm{Ru}_{0.4} \mathrm{O}_{2}$ powders are porous with BET surface areas between 50 and $90 \mathrm{~m}^{2} \mathrm{~g}^{-1}$ (Fig. 2e and Supplementary Table 2). Barrett-Joyner-Halenda (BJH) pore size analysis reveals that the pore sizes of $\mathrm{Cr}_{0.6} \mathrm{Ru}_{0.4} \mathrm{O}_{2}$ particle are larger than $10 \mathrm{~nm}$ (generated from the aggregation of nanocrystals in an individual particle as shown in TEM images) and increase with the annealing temperature (Supplementary Figure 9). This trend can be ascribed to the larger volume contraction of $\mathrm{Cr}_{0.6} \mathrm{Ru}_{0.4} \mathrm{O}_{2}$ nanocrystals within a single particle at higher annealing temperature. High-angle annular dark-field scanning transmission electron microscopy (HAADF-STEM) was employed to analyze the element distribution in a single nanocrystal. The resulting EDS mapping images (Fig. 3g) show that $\mathrm{Cr}, \mathrm{Ru}$, and $\mathrm{O}$ are uniformly distributed over the entire $\mathrm{Cr}_{0.6} \mathrm{Ru}_{0.4} \mathrm{O}_{2}$ nanocrystal, demonstrating the formation of a single phase of $\mathrm{Cr}$ and $\mathrm{Ru}$ oxide solid solution (the mapping images for a wider region are shown in Supplementary Figure 10). In addition, the EDS analysis indicates that $\mathrm{Cr} / \mathrm{Ru}$ ratio is $0.56: 0.44$, generally consistent with the ICP-MS result (Supplementary Figure 11). Furthermore, we performed atomic-resolution HAADF-STEM and electron energy loss spectroscopy (EELS) mapping characterization. As shown in Fig. $3 \mathrm{~h}-\mathrm{j}$, the atomicsolution HAADF-STEM images clearly demonstrate the well crystalized single nanocrystals. EELS analysis of a randomly selected region in a single nanocrystal confirmed the coexistence of $\mathrm{Ru}$ and $\mathrm{Cr}$ atoms. The corresponding EELS elemental mapping with subnanometer resolution (Fig. $3 \mathrm{k}$ ) also shows a uniform uncorrelated spatial distribution of $\mathrm{Cr}, \mathrm{Ru}$, and $\mathrm{O}$.
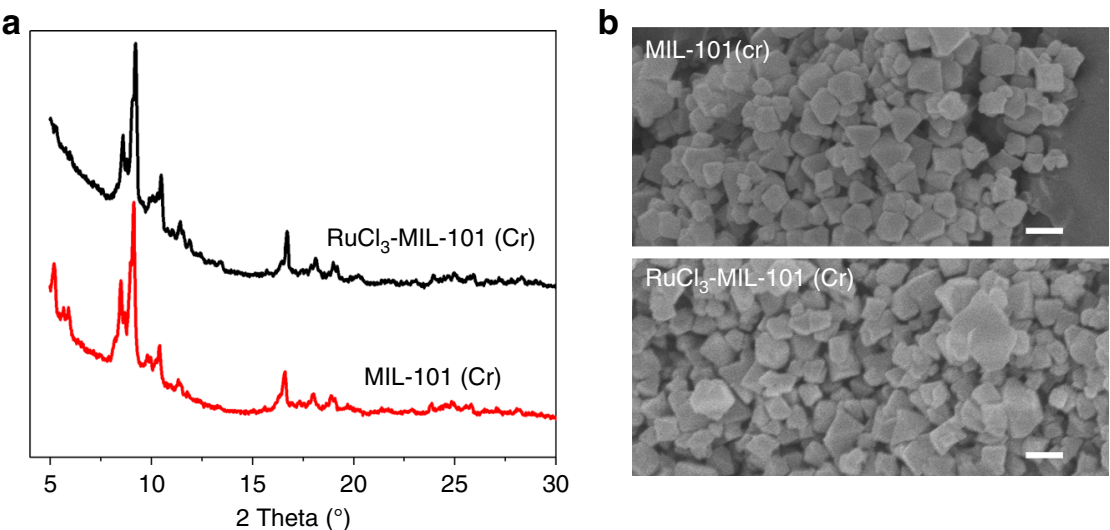

d
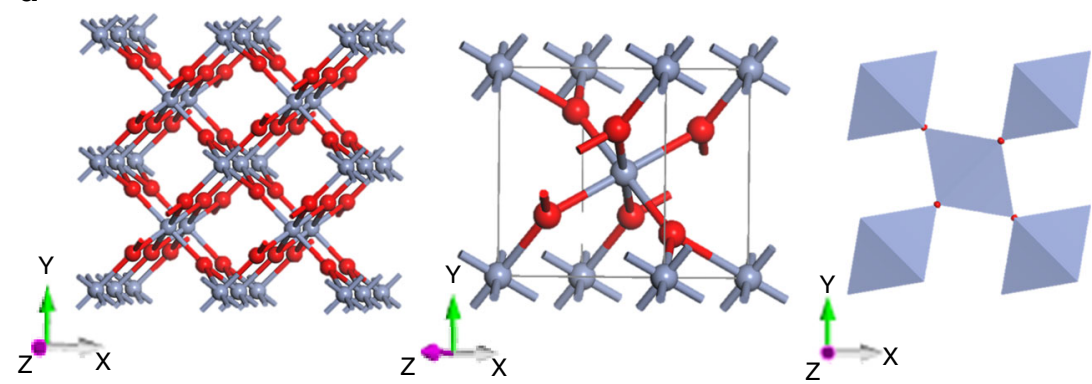
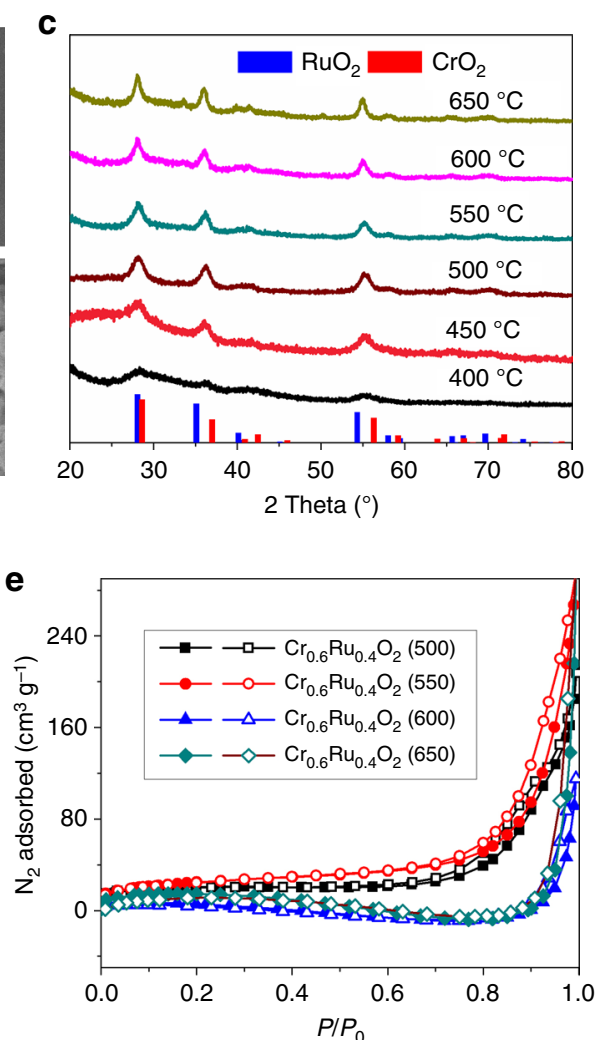

Fig. 2 Structural characterizations of $\mathrm{RuCl}_{3}-\mathrm{MIL}-101\left(\mathrm{Cr}\right.$ ) and $\mathrm{Cr}_{0.6} \mathrm{Ru}_{0.4} \mathrm{O}_{2}$ (550). a, b PXRD patterns and SEM images of MIL-101 (Cr) before and after loading $\mathrm{RuCl}_{3}$ (scale bars, $200 \mathrm{~nm}$ ); c PXRD patterns of $\mathrm{Cr}_{0.6} \mathrm{Ru}_{0.4} \mathrm{O}_{2}$ powders annealed at different temperatures. The reference patterns of $\mathrm{CrO}_{2}$ and $\mathrm{RuO}_{2}$ were obtained from Jade 2004 (JCPDS No.09-0332 and 43-1027); d Crystal structure of $\mathrm{Cr}_{0.6} \mathrm{Ru}_{0.4} \mathrm{O}_{2}$ (550): (left) packing image, (middle) unit cell, (right) corner shared octahedral $\mathrm{MO}_{6}$ structure. Color code: blue $\left(60 \% \mathrm{Ru}, 40 \% \mathrm{Cr}\right.$ ), red (O). e $77 \mathrm{~K} \mathrm{~N}_{2}$ adsorption/desorption isotherms of $\mathrm{Cr}_{0.6} \mathrm{Ru}_{0.4} \mathrm{O}_{2}$ powders annealed at different temperatures 

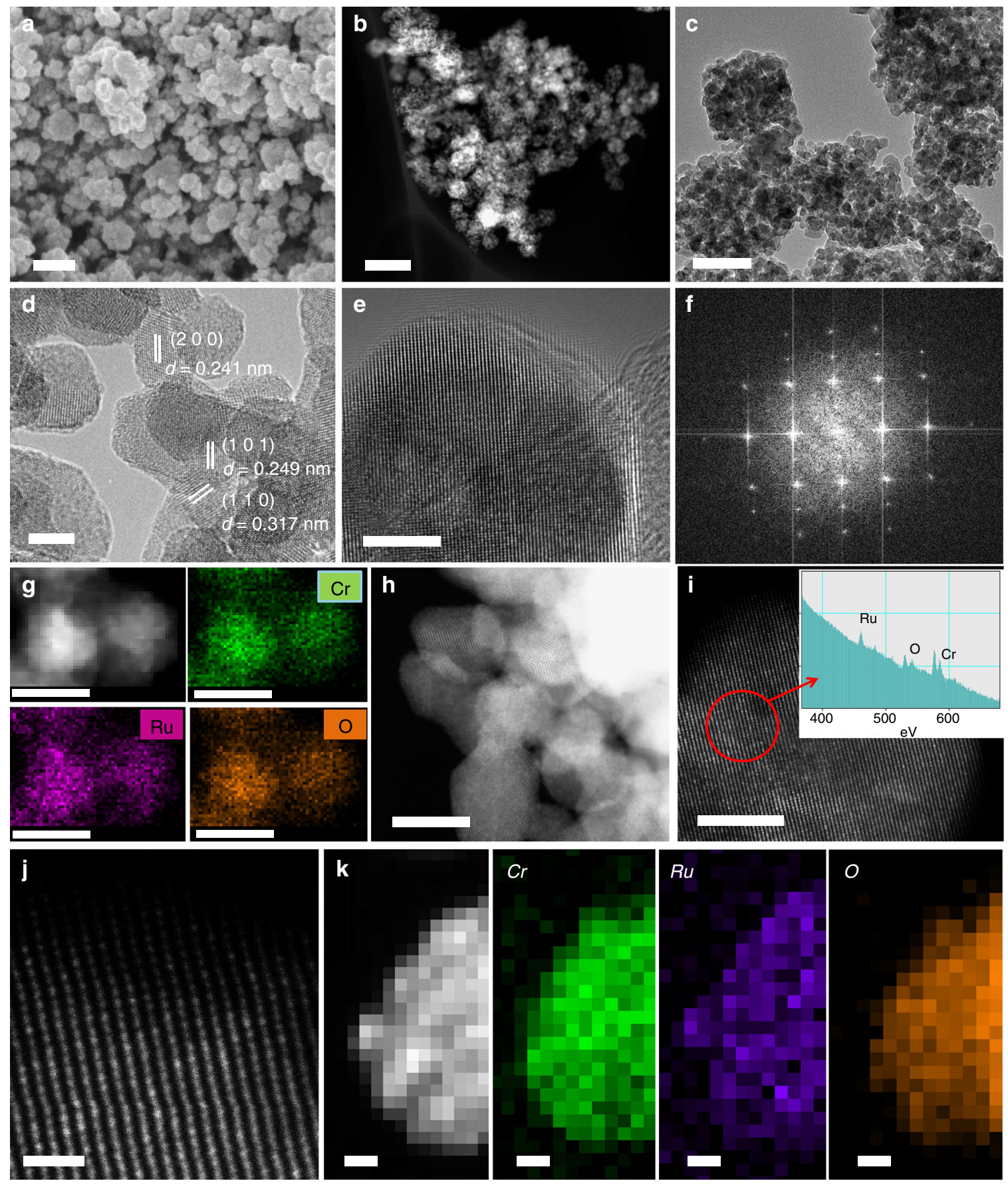

Fig. 3 Morphology and elemental mapping images of $\mathrm{Cr}_{0.6} \mathrm{Ru}_{0.4} \mathrm{O}_{2}$ (550). a SEM image (scale bar, $200 \mathrm{~nm}$ ); b Dark field TEM image (scale bar, $200 \mathrm{~nm}$ ); c TEM image (scale bar, $50 \mathrm{~nm}$ ); d HR-TEM image (scale bar, $5 \mathrm{~nm}$ ); e HR-TEM image of a single nanocrystal (scale bar, $5 \mathrm{~nm}$ ); $\mathbf{f}$ The corresponding FFT image; $\mathbf{g}$ HAADF-STEM image, corresponding EDS element mapping showing the distribution of $\mathrm{Cr}$, Ru, and $\mathrm{O}$ (scale bars, $10 \mathrm{~nm}$ ); $\mathbf{h}-\mathbf{j}$ atomic-resolution HAADF-STEM images and EELS analysis (inset of i), scale bars: 10, 5, and $1 \mathrm{~nm}$, respectively; $\mathbf{k}$ EELS maps (scale bars, $1 \mathrm{~nm}$ )

OER catalytic performance in strong acidic media. The OER activity of $\mathrm{Cr}_{0.6} \mathrm{Ru}_{0.4} \mathrm{O}_{2}$ powders annealed at different temperatures was studied in a strong acidic media $\left(0.5 \mathrm{M} \mathrm{H}_{2} \mathrm{SO}_{4}\right)$. The $\mathrm{Cr}_{0.6} \mathrm{Ru}_{0.4} \mathrm{O}_{2}$ based electrodes were prepared by drop-casting a water/ethanol and Nafion-based ink of $\mathrm{Cr}_{0.6} \mathrm{Ru}_{0.4} \mathrm{O}_{2}$ on the glassy carbon disk (see more details in methods section). Figure 4a shows the linear sweep voltammetry (LSV) results, where the rising current indicates the region where oxygen evolution occurred. $\mathrm{Cr}_{0.6} \mathrm{Ru}_{0.4} \mathrm{O}_{2}$ (450), $\mathrm{Cr}_{0.6} \mathrm{Ru}_{0.4} \mathrm{O}_{2}$ (500) and $\mathrm{Cr}_{0.6} \mathrm{Ru}_{0.4} \mathrm{O}_{2}$ (550) exhibit excellent initial OER activities, with onset potential of $\sim 1.33 \mathrm{~V}$ vs. RHE, which represents an overpotential of $\sim 100$
$\mathrm{mV}$. In addition, according to the suggested benchmark criteria ${ }^{33}$, $\mathrm{Cr}_{0.6} \mathrm{Ru}_{0.4} \mathrm{O}_{2}$ (450), $\mathrm{Cr}_{0.6} \mathrm{Ru}_{0.4} \mathrm{O}_{2}$ (500), and $\mathrm{Cr}_{0.6} \mathrm{Ru}_{0.4} \mathrm{O}_{2}$ (550) exhibited overpotentials of 175,178 and $178 \mathrm{mV}$ at the current density of $10 \mathrm{~mA} \mathrm{~cm}{ }^{-2}$, respectively. $\mathrm{Cr}_{0.6} \mathrm{Ru}_{0.4} \mathrm{O}_{2}$ (600) and $\mathrm{Cr}_{0.6} \mathrm{Ru}_{0.4} \mathrm{O}_{2}$ (650) show slightly higher OER overpotentials (186 and $200 \mathrm{mV}$ at $10 \mathrm{~mA} \mathrm{~cm}^{-2}$, respectively), but still lower than those reported in literatures ${ }^{23,25}$. Note that there is little difference in the PXRD patterns for $\mathrm{Cr}_{0.6} \mathrm{Ru}_{0.4} \mathrm{O}_{2}$ electrocatalysts annealed above $500^{\circ} \mathrm{C}$, the slightly lower OER activity for $\mathrm{Cr}_{0.6} \mathrm{Ru}_{0.4} \mathrm{O}_{2}$ (600) and $\mathrm{Cr}_{0.6} \mathrm{Ru}_{0.4} \mathrm{O}_{2}$ (650) might be ascribed to the lattice strain, which was also observed on $\mathrm{IrO}_{2}{ }^{34}$. 

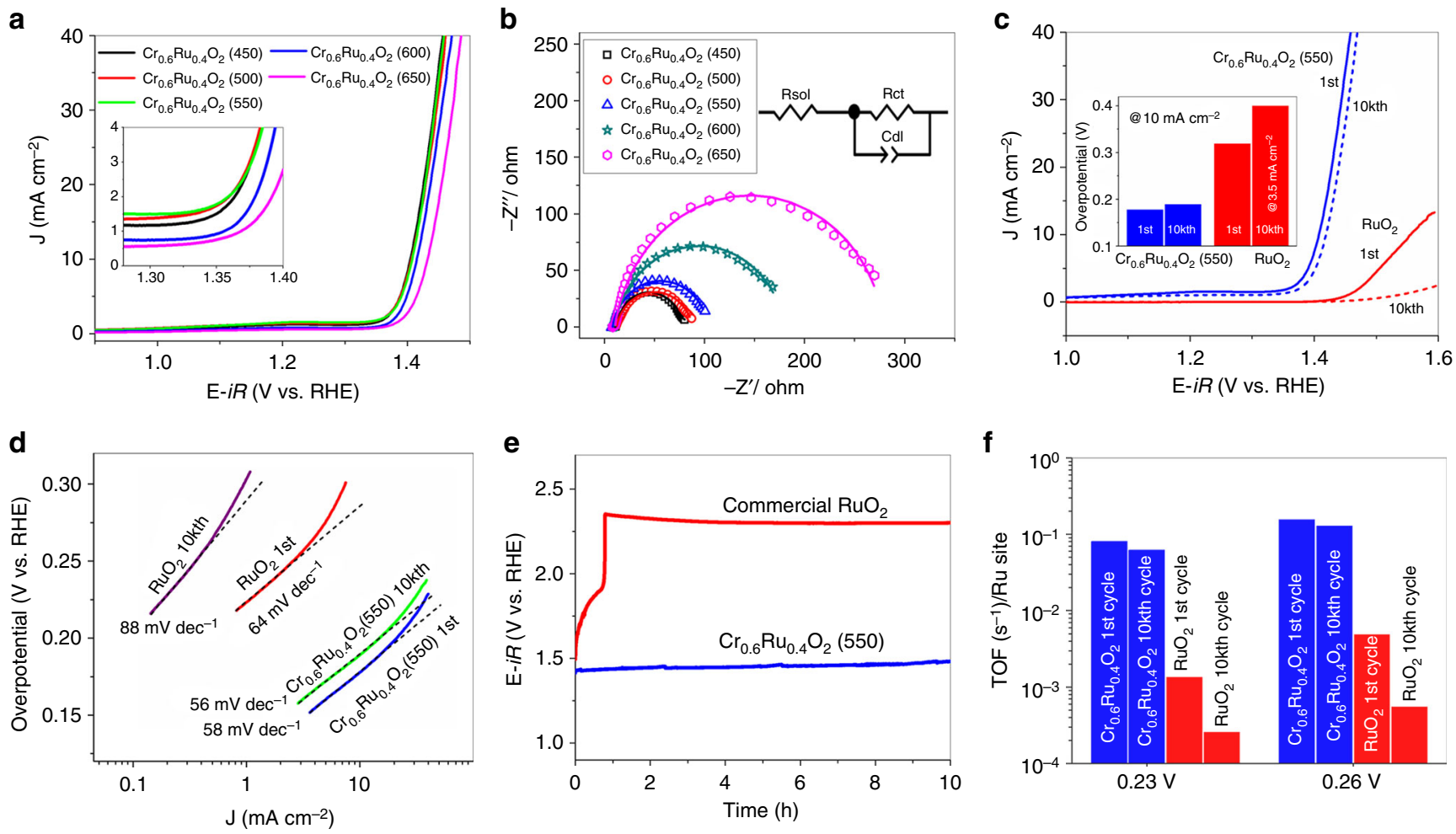

Fig. 4 OER activity of $\mathrm{Cr}_{0.6} \mathrm{Ru}_{0.4} \mathrm{O}_{2}$ annealed at different temperature. a Electrocatalytic OER activities of $\mathrm{Cr}_{0.6} \mathrm{Ru}_{0.4} \mathrm{O}_{2}$ (450-650) nanoparticiles; b Nyquist plots at $1.395 \mathrm{~V}$. Solid curves are the fitting results by using the equivalent circuit shown in the inset; $\mathbf{c} \mathrm{LSVs}_{\mathrm{s}}$ of $\mathrm{Cr}_{0.6} \mathrm{Ru}_{0.4} \mathrm{O}_{2}(550)$ and commerical RuO for the first and 10,000th cycle. Inset shows the comprarsion of overpotentials for $\mathrm{Cr}_{0.6} \mathrm{Ru}_{0.4} \mathrm{O}_{2}(550)$ and $\mathrm{RuO}_{2}$ at the current density of $10 \mathrm{~mA}$ cm ${ }^{-2}$ at the first and 10,000 th cycle. For $\mathrm{RuO}_{2}$ after 10,000 cycles, the overpotential is corresponded to $3.5 \mathrm{~mA} \mathrm{~cm}^{-2}$ which is the maxium current density of its LSV curve; $\mathbf{d}$ Tafel plots of $\mathrm{Cr}_{0.6} \mathrm{Ru}_{0.4} \mathrm{O}_{2}$ (550) and $\mathrm{RuO}_{2}$ at first and 10,000th cycle; e Chronopotentiometry performance under constant current density of $10 \mathrm{~mA} \mathrm{~cm}{ }^{-2}$ up to $10 \mathrm{~h}$. $\mathbf{f}$ TOF results of $\mathrm{Cr}_{0.6} \mathrm{Ru}_{0.4} \mathrm{O}_{2}$ (550) and $\mathrm{RuO}_{2}$ at the first and 10,000 th cycle

Electrochemical impedance spectroscopy (EIS) measurement was further employed to reveal the catalytic property during OER. As shown in Fig. 4b, all the EIS spectra (Nyquist plots) at $1.395 \mathrm{~V}$ display a depressed semicircle, suggesting a charge-transfer process during the OER. These Nyquist plots can be well fitted by a simple equivalent electrical circuit which is composed of three components: solution resistance $\left(R_{\text {sol }}\right)$, charge transfer resistance $\left(R_{\mathrm{ct}}\right)$, and double layer capacitance $\left(C_{\mathrm{dl}}\right)^{35-37}$. The charge transfer resistance of $\mathrm{Cr}_{0.6} \mathrm{Ru}_{0.4} \mathrm{O}_{2}$ electrocatalyst generally increases with the applied annealing temperature. The larger charge transfer resistance for $\mathrm{Cr}_{0.6} \mathrm{Ru}_{0.4} \mathrm{O}_{2}$ electrocatalyst at higher annealing temperature can also be attributed to the lattice strain effects ${ }^{34}$. For $\mathrm{Cr}_{0.6} \mathrm{Ru}_{0.4} \mathrm{O}_{2}$ (550), the charge transfer resistance is $97.2 \Omega$, which is much smaller than that of commercial $\mathrm{RuO}_{2}(>4000 \Omega)$ tested under the same conditions (Supplementary Figure 12, Supplementary Table 3), demonstrating a much faster kinetics for OER. Here the high Rct of commercial $\mathrm{RuO}_{2}$ is due to the fact that the OER reactions on $\mathrm{RuO}_{2}$ catalyst do not occur at $1.395 \mathrm{~V}$. We thus measured the EIS spectra of $\mathrm{RuO}_{2}$ at higher voltages (Supplementary Figure 13). It shows that the Rct of $\mathrm{RuO}_{2}$ dramatically decreased with the increasing voltage applied. At $1.55 \mathrm{~V}$, the Rct is $45.6 \Omega$, and the corresponding area-specific Rct is $3.2 \Omega \mathrm{cm}^{2}$, comparable to those of literatures reported ${ }^{38}$. In addition, we also measured the EIS spectra of $\mathrm{Cr}_{0.6} \mathrm{Ru}_{0.4} \mathrm{O}_{2}$ (550) at higher voltages (Supplementary Figure 14). The results showthat $\mathrm{Cr}_{0.6} \mathrm{Ru}_{0.4} \mathrm{O}_{2}$ (550) has rather small $\mathrm{Rct}$, with a value of $10.6 \Omega$ at $1.47 \mathrm{~V}$, corresponding to the area-specific Rct value of $0.7 \Omega \mathrm{cm}^{2}$. The durability of $\mathrm{Cr}_{0.6} \mathrm{Ru}_{0.4} \mathrm{O}_{2}$ electrocatalysts were assessed by cycling the catalysts between 1.2 and $1.6 \mathrm{~V}$ at a sweep rate of $100 \mathrm{mV} \mathrm{s}^{-1}$ in $0.5 \mathrm{M} \mathrm{H}_{2} \mathrm{SO}_{4}$ for 10,000 cycles. For $\mathrm{Cr}_{0.6} \mathrm{Ru}_{0.4} \mathrm{O}_{2}$ electrocatalyst annealed at $450{ }^{\circ} \mathrm{C}$, the overpotential (at $10 \mathrm{~mA} \mathrm{~cm}^{-2}$ ) dramatically decreased from $177 \mathrm{mV}$ at the first cycle to $242 \mathrm{mV}$ at the 10,000th cycle (Supplementary Figure 15) due to the relatively unstable structures under the acidic solutions. In contrast, $\mathrm{Cr}_{0.6} \mathrm{Ru}_{0.4} \mathrm{O}_{2}$ electrocatalyst annealed above $500{ }^{\circ} \mathrm{C}$ exhibited stable OER performance, with slight overpotential decrease $\left(<20 \mathrm{mV}\right.$ at $\left.10 \mathrm{~mA} \mathrm{~cm}^{-2}\right)$ after 10,000 cycles (Supplementary Figure 15). Notably, $\mathrm{Cr}_{0.6} \mathrm{Ru}_{0.4} \mathrm{O}_{2}$ (550) showed only $11 \mathrm{mV}$ overpotential decrease (at $10 \mathrm{~mA} \mathrm{~cm}^{-2}$ ) after 10,000 cycles (Fig. 4c). The high stability of $\mathrm{Cr}_{0.6} \mathrm{Ru}_{0.4} \mathrm{O}_{2}$ (550) was also confirmed by TEM images of $\mathrm{Cr}_{0.6} \mathrm{Ru}_{0.4} \mathrm{O}_{2}$ (550) after 10,000 cycles, where no crystallinity or morphology change was observed (Supplementary Figure 16). In addition, the ICP-MS experiments (Supplementary Table 4) show that less than $2.5 \% \mathrm{Ru}$ and $8 \% \mathrm{Cr}$ of $\mathrm{Cr}_{0.6} \mathrm{Ru}_{0.4} \mathrm{O}_{2}$ (550) were dissolved in the acidic electrolyte solution after 10,000 cycles, which results in the slight degradation of OER performance. Note that such leaching content is smaller than those of recently reported excellent OER catalysts for acidic condition ${ }^{23,27}$.

In terms of both activity and stability, $\mathrm{Cr}_{0.6} \mathrm{Ru}_{0.4} \mathrm{O}_{2}$ (550) represents the best-performance OER electrocatalyst among the $\mathrm{Cr}_{0.6} \mathrm{Ru}_{0.4} \mathrm{O}_{2}$ electrocatalysts annealed between 450 and $650{ }^{\circ} \mathrm{C}$, with overpotential (at $10 \mathrm{~mA} \mathrm{~cm}^{-2}$ ) of $178 \mathrm{mV}$ at the first cycle and $189 \mathrm{mV}$ at the 10,000th cycle. For further comparison, the OER performance of commercial $\mathrm{RuO}_{2}$ powder with particle size of $\sim 30 \mathrm{~nm}$ (Supplementary Figure 17) was also tested under the same conditions. As shown in Fig. $4 \mathrm{c}, \mathrm{RuO}_{2}$ exhibited much lower activity and stability compared to $\mathrm{Cr}_{0.6} \mathrm{Ru}_{0.4} \mathrm{O}_{2}$ (550). The 
overpotential at 1 and $10 \mathrm{~mA} \mathrm{~cm}^{-2}$ of $\mathrm{RuO}_{2}$ were measured to be $240 \mathrm{mV}$ and $297 \mathrm{mV}$, respectively, which are consistent with those reported in literatures (Supplementary Table 5) ${ }^{38}$. After 10,000 cycles, the OER activity was dramatically decreased and became even negligible compared to the initial cycle. Figure $4 \mathrm{~d}$ shows the Tafel plots of $\mathrm{Cr}_{0.6} \mathrm{Ru}_{0.4} \mathrm{O}_{2}$ (550) and $\mathrm{RuO}_{2}$ at the first and 10,000th cycle. The Tafel slope for $\mathrm{RuO}_{2}$ dramatically rose

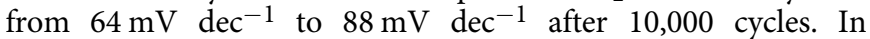
contrast, the Tafel slope for $\mathrm{Cr}_{0.6} \mathrm{Ru}_{0.4} \mathrm{O}_{2}$ (550) slightly decreased

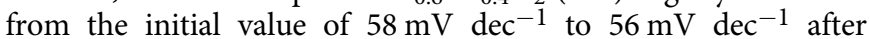
10,000 cycles. To further confirm the difference on stability of $\mathrm{Cr}_{0.6} \mathrm{Ru}_{0.4} \mathrm{O}_{2}$ (550) and $\mathrm{RuO}_{2}$ in catalytic performance, chronopotentiometry was examined under a constant current density. According to the suggested benchmark criteria in previous reports 23,33 , a current density of $10 \mathrm{~mA} \mathrm{~cm}^{-2}$ was used in the present study. Figure $4 \mathrm{e}$ shows the corresponding potential change for both $\mathrm{Cr}_{0.6} \mathrm{Ru}_{0.4} \mathrm{O}_{2}$ (550) and $\mathrm{RuO}_{2}$. The potential for $\mathrm{RuO}_{2}$ electrocatalyst changed from 1.5 to $1.9 \mathrm{~V}$ in $40 \mathrm{~min}$ and rose sharply to $2.19 \mathrm{~V}$, essentially losing all its activity. On the contrary, the $\mathrm{Cr}_{0.6} \mathrm{Ru}_{0.4} \mathrm{O}_{2}$ (550) electrocatalyst remained essentially stable throughout the $10 \mathrm{~h}$ chronopotentiometry test. Furthermore, the turnover frequency (TOF) of $\mathrm{Cr}_{0.6} \mathrm{Ru}_{0.4} \mathrm{O}_{2}$ (550) and $\mathrm{RuO}_{2}$ was also calculated by dividing the number of oxygen molecules generated by the number of Ru sites under an assumed $100 \%$ Faradaic efficiency (Fig. $4 \mathrm{f}$ ) ${ }^{39} \cdot \mathrm{Cr}_{0.6} \mathrm{Ru}_{0.4} \mathrm{O}_{2}$ (550) showed a TOF value of $0.15 \mathrm{~s}^{-1}$ at the overpotential of $260 \mathrm{mV}$ for the first cycle and slightly decreased to $0.13 \mathrm{~s}^{-1}$ for the 10,000 th cycle. However, under the same condition, the TOF of $\mathrm{RuO}_{2}$ was decreased by an order of magnitude, changing from $4.9 \times 10^{-3} \mathrm{~s}^{-1}$ at the first cycle to $5.5 \times 10^{-4} \mathrm{~s}^{-1}$ for the 10,000 th cycle. The same TOF change trend was also observed at an overpotential of $230 \mathrm{mV}$. It should be noted that all the $\mathrm{Ru}$ atoms including inaccessible ones in bulk were treated as surface sites in this TOF calculation, which thus underestimated the true TOF values ${ }^{40}$. In addition, we further calculated the electrochemically active surface area (ECSA), roughness factor of $\mathrm{Cr}_{0.6} \mathrm{Ru}_{0.4} \mathrm{O}_{2}(550)$ and $\mathrm{RuO}_{2}$ electrode, and plotted the LSVs with respect to the ECSA (Supplementary Figure 18-20, Supplementary Table 6). The results show that the enhanced activity of OER performance of $\mathrm{CrO}_{2}-\mathrm{RuO}_{2}$ solid solution is not just enhanced by the ECSA, and the intrinsic activity arising from the $\mathrm{Cr}$ ions plays an more important role.

In short, $\mathrm{Cr}_{0.6} \mathrm{Ru}_{0.4} \mathrm{O}_{2}$ (550) exhibits superior OER performance compared to $\mathrm{RuO}_{2}$ catalysts or other $\mathrm{RuO}_{2}$-based catalysts reported to date. Notably, it even outperforms the $\mathrm{IrO}_{2}$-based catalysts, which represent the state-of-the-art electrocatalyst for OER in acidic media (Table 1). An exhaustive comparison with other reported OER catalysts in acidic media is shown in Supplementary Table 7. It shows that the mass activity of $\mathrm{Cr}_{0.6} \mathrm{Ru}_{0.4} \mathrm{O}_{2}(550)$ at $270 \mathrm{mV}\left(229 \mathrm{~A} \mathrm{~g}^{-1}\right)$ is also much higher than those reported in literatures. In addition, the OER performance of $\mathrm{CrO}_{2}$ powder was also measured as a reference. As expected, no OER activity was observed on $\mathrm{CrO}_{2}$ powder (Supplementary Figure 21), suggesting that the synergic effects of $\mathrm{Ru}(\mathrm{IV})$ and $\mathrm{Cr}$ (IV) components in $\mathrm{Cr}_{0.6} \mathrm{Ru}_{0.4} \mathrm{O}_{2}$ structure are responsible for the excellent OER performance.

We further synthesized a series of $\mathrm{Cr}-\mathrm{Ru}$ oxides with different $\mathrm{Cr}$ ratios to investigate the $\mathrm{Cr}$ role on the catalytic property. By varying the mass of $\mathrm{RuCl}_{3}$ in THF solution, we prepared MIL$101-\mathrm{RuCl}_{3}$ precursors with different $\mathrm{RuCl}_{3}$ loading, and then obtained $\mathrm{Cr}-\mathrm{Ru}$ oxides with $\mathrm{Cr} / \mathrm{Ru}$ ratios varying from 9:1 to 6:4 after annealing $(\mathrm{Cr} / \mathrm{Ru}$ ratios were determined by ICP-MS measurements). Figure 5 shows the corresponding morphology and structure evolution of $\mathrm{Cr}-\mathrm{Ru}$ oxides. Directly annealing MIL$101(\mathrm{Cr})$ without loading $\mathrm{RuCl}_{3}$ at $450{ }^{\circ} \mathrm{C}$, we only obtained $\mathrm{Cr}_{2} \mathrm{O}_{3}$ nanoparticles with high crystallinity (Supplementary Figure 22).
After loading $\mathrm{RuCl}_{3}$ into MIL-101 (Cr), $\mathrm{CrO}_{2}-\mathrm{RuO}_{2}$ solid solution phase started to emerge after annealing. This is because $\mathrm{RuO}_{2}$ and $\mathrm{CrO}_{2}$ share the same rutile structure and have similar lattice constants, and the presence of $\mathrm{Ru}$ would induce the formation of $\mathrm{RuO}_{2}-\mathrm{CrO}_{2}$ solid solution. For $\mathrm{Cr}_{0.91} \mathrm{Ru}_{0.09} \mathrm{O}_{2-\delta}$ and $\mathrm{Cr}_{0.83} \mathrm{Ru}_{0.17} \mathrm{O}_{2-\delta}$ ( $\delta$ was used to balance the valance of $\mathrm{Cr}^{3+}$ for the powders with mixed phase of $\mathrm{Cr}_{2} \mathrm{O}_{3}$ and $\mathrm{CrO}_{2}-\mathrm{RuO}_{2}$ solid solution) with low $\mathrm{Ru}$ content, the major phase is still $\mathrm{Cr}_{2} \mathrm{O}_{3}$, which can be clearly observed from the PXRD patterns in Fig. 5e. In contrast, for $\mathrm{Cr}_{0.72} \mathrm{Ru}_{0.28} \mathrm{O}_{2-\delta}$ with higher $\mathrm{Ru}$ content, the $\mathrm{CrO}_{2}-\mathrm{RuO}_{2}$ solid solution turn to be the major phase, and for $\mathrm{Cr}_{0.67} \mathrm{Ru}_{0.33} \mathrm{O}_{2}$ and $\mathrm{Cr}_{0.6} \mathrm{Ru}_{0.4} \mathrm{O}_{2}$, pure phase of $\mathrm{CrO}_{2}-\mathrm{RuO}_{2}$ solid solution was formed. Note that, all the peaks shift slightly to the left side as the $\mathrm{Ru}$ content increases, which is a characteristic of $\mathrm{RuO}_{2}-\mathrm{CrO}_{2}$ solid solution. We further calculated the lattice parameters of $\mathrm{Cr}_{1-\mathrm{x}} \mathrm{Ru}_{\mathrm{x}} \mathrm{O}_{2}$ with solid solution as the major or pure phase (i.e., $\mathrm{Cr}_{0.72} \mathrm{Ru}_{0.28} \mathrm{O}_{2-\delta}, \mathrm{Cr}_{0.67} \mathrm{Ru}_{0.33} \mathrm{O}_{2}$, and $\mathrm{Cr}_{0.6} \mathrm{Ru}_{0.4} \mathrm{O}_{2}$ ). As shown in Supplementary Figure 23, the c parameter varies nearly linearly with the composition. This quasi-linear relationship is in good agreement with the Vegard's law. Although the shift of the $a$ parameter shows the same trend as the $c$ parameter when the $\mathrm{Ru}$ content increases, there is a deviation for the $a$ parameter according to the Vegard's law. This deviation was possibly due to the little difference of $a$ parameter between $\mathrm{RuO}_{2}(a=4.499 \AA)$ and $\mathrm{CrO}_{2}(a=4.421 \AA)$, and/or the existence of some defects in the lattice along the $a$ axis $^{41,42}$. It is noteworthy that there is a pre-oxidation peak of the solid solution samples, which can be ascribed to the pre-oxidation of $\mathrm{Cr}$. However, no such preoxidation peak was observed on $\mathrm{Cr}_{2} \mathrm{O}_{3}$ sample annealed at $450^{\circ} \mathrm{C}$, which can be attributed to its large crystal size (Supplementary Figure 24a) and relatively low active surface area that could cause low conductivity and activity. We thus prepared $\mathrm{Cr}_{2} \mathrm{O}_{3}$ with much smaller particle sizes (Supplementary Figures 22 and 24b) by annealing MIL-101(Cr) at lower temperature $\left(300^{\circ} \mathrm{C}\right)$. Indeed, herein we also observed this preoxidation peak on the $\mathrm{Cr}_{2} \mathrm{O}_{3}$ with less crystallinity (Supplementary Figure 25), albeit the peak was weak. The position of preoxidation peak of $\mathrm{Cr}_{2} \mathrm{O}_{3}$ was slightly higher than that of $\mathrm{Cr}_{1}$ ${ }_{\mathrm{x}} \mathrm{Ru}_{\mathrm{x}} \mathrm{O}_{2}$, which was possibly due to the synergistic effect of $\mathrm{Cr}$ and $\mathrm{Ru}$ in $\mathrm{Cr}_{1-\mathrm{x}} \mathrm{Ru}_{\mathrm{x}} \mathrm{O}_{2}$. Due to the saturation adsorption limit, we are unable to prepare $\mathrm{Cr}-\mathrm{Ru}$ oxides with $\mathrm{Cr} / \mathrm{Ru}$ ratio lower than $0.6 /$ 0.4. LSV results show that the OER performance of $\mathrm{Cr}-\mathrm{Ru}$ oxides is highly correlated to the $\mathrm{Ru} / \mathrm{Cr}$ ratio. $\mathrm{Cr}_{0.91} \mathrm{Ru}_{0.09} \mathrm{O}_{2-\delta}$ and $\mathrm{Cr}_{0.83} \mathrm{Ru}_{0.17} \mathrm{O}_{2-\delta}$ show moderate performance due to the high content of inactive $\mathrm{Cr}_{2} \mathrm{O}_{3}$ phase. With increasing $\mathrm{Ru}$ composition, the OER activity can be dramatically improved because the $\mathrm{CrO}_{2}-\mathrm{RuO}_{2}$ solid solution evolved as the major phase or even pure phase (Fig. 5f). However, it is noteworthy that the OER performance of $\mathrm{Cr}_{0.91} \mathrm{Ru}_{0.09} \mathrm{O}_{2}$ with small amount of $\mathrm{CrO}_{2}-\mathrm{RuO}_{2}$ solid solution phase is still higher than that of $\mathrm{RuO}_{2}$, highlighting the crucial role of $\mathrm{Cr}$ ions on the improved activity towards OER. We also measured the OER performance of mixed $\mathrm{RuO}_{2}$ and $\mathrm{CrO}_{2}$ sample. The result shows that mixed $\mathrm{RuO}_{2}$ and $\mathrm{CrO}_{2}$ has very poor OER performance, even much lower than that of pristine $\mathrm{RuO}_{2}$. Note that the conductivity plays an important role in the OER process, and it might not be a good comparison to the chromium-ruthenium oxides if some residual carbon species inherent from MOF precursor exist in our samples. Therefore, we further preformed Raman and thermogravimetric (TG) measurement of the samples to detect the residual carbon. As shown in Supplementary Figures 26 and 27, no signal of the residual carbon can be observed. Nevertheless, we added carbonaceous additive (commercial acetylene black that has high conductivity) to the mixed $\mathrm{CrO}_{2}-\mathrm{RuO}_{2}$, denoted as mixed $\mathrm{CrO}_{2}-\mathrm{RuO}_{2} / \mathrm{C}$. As shown in Supplementary Figure 28, the OER activity of mixed $\mathrm{CrO}_{2}-\mathrm{RuO}_{2} / \mathrm{C}$ was enhanced after the addition of carbon black, 
Table 1 Selected catalysts with high OER performance

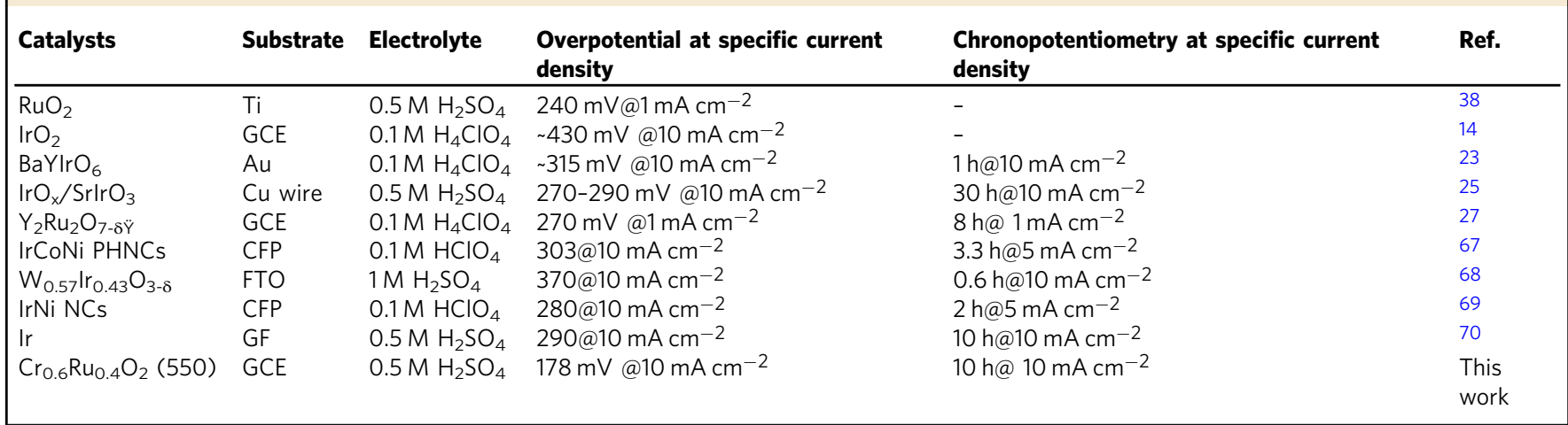

but still lower than that of pure $\mathrm{RuO}_{2}$, indicating the important synergistic effect of $\mathrm{Cr}^{4+}$ role as a participating lattice ion.

Intrinsic mechanism for the excellent OER performance. We first performed X-ray photoelectron spectroscopy (XPS) to access the surface chemical state of $\mathrm{Cr}_{0.6} \mathrm{Ru}_{0.4} \mathrm{O}_{2}$ (550). As shown in Fig. $6 \mathrm{a}$, there are two sets of doublet peaks for $\mathrm{Ru} 3 d$ in the region between 280 and $290 \mathrm{eV}$, corresponding to the doublet peaks for $\mathrm{Ru}$ (IV) $3 d_{5 / 2}, 3 d_{3 / 2}$ and their satellite peaks ${ }^{43}$. The primary $\mathrm{Ru}$ $3 d_{5 / 2}$ and $3 d_{3 / 2}$ peaks of $\mathrm{RuO}_{2}$ centered at 280.6 and $284.8 \mathrm{eV}$, respectively, which are consistent with literatures ${ }^{44,45}$. A shift to higher binding energy can be clearly observed on $\mathrm{Cr}_{0.6} \mathrm{Ru}_{0.4} \mathrm{O}_{2}$ (550) compared to $\mathrm{RuO}_{2}$, suggesting a lower electron density at the $\mathrm{Ru}$ sites. This can be attributed to the electron withdrawing effect of $\mathrm{Cr}$ (IV) in the lattice. Note that the observed C1s peaks are resulting from the carbon adhesive tape used in XPS measurement and environmental corrosion carbon. Indeed, as mentioned above, Raman characterization and thermogravimetric analysis confirmed that there is negligible carbon component in the $\mathrm{Cr}_{0.6} \mathrm{Ru}_{0.4} \mathrm{O}_{2}$ catalysts (Supplementary Figures 26 and 27). For Cr $2 p$, three sets of doublet peaks can be observed on $\mathrm{Cr}_{0.6} \mathrm{Ru}_{0.4} \mathrm{O}_{2}$ (550) and $\mathrm{CrO}_{2}$ in the region between 570 and $595 \mathrm{eV}$ (Fig. 6b). The primary peaks at $\sim 576.0 \mathrm{eV}$ correspond to $\mathrm{Cr}$ (IV) $2 p_{3 / 2} 46,47$. For Cr (IV) $2 p_{3 / 2}$ of $\mathrm{Cr}_{0.6} \mathrm{Ru}_{0.4} \mathrm{O}_{2}$ (550), a shift to lower binding energy is observed compared to $\mathrm{CrO}_{2}$, implying a higher electron density at $\mathrm{Cr}$ sites, which confirms the withdrawing effect of $\mathrm{Cr}$ (IV) in $\mathrm{Cr}_{0.6} \mathrm{Ru}_{0.4} \mathrm{O}_{2}$ (550). For the other two peaks in the $\mathrm{Cr} 2 p_{3 / 2}$ region, the smaller ones at $\sim 575.0 \mathrm{eV}$ can be assigned to $\mathrm{Cr}$ (III) $2 p_{3 / 2}$, which implies the appearance of a small amount of $\mathrm{Cr}$ (III) sites on the outer surface of $\mathrm{Cr}_{0.6} \mathrm{Ru}_{0.4} \mathrm{O}_{2}$ (550) and $\mathrm{CrO}_{2}$ crys$\operatorname{tals}^{47,48}$, and the larger ones at $\sim 577.9 \mathrm{eV}$ can be assigned to $\mathrm{CrO}_{2} \mathrm{H}$, which likely resulted from the reaction between $\mathrm{Cr}$ (IV) and the proton from environment ${ }^{49}$. Additional XPS spectra for wide scan and $\mathrm{Ru} 3 p$ regions are shown in Supplementary Figures 29 and 30 .

To elucidate the atomic structure of $\mathrm{Cr}_{0.6} \mathrm{Ru}_{0.4} \mathrm{O}_{2}(550)$, X-ray absorption spectroscopy (XAS) characterization was further employed. Figure $7 \mathrm{a}$ shows the $\mathrm{X}$-ray absorption near edge structure (XANES) of $\mathrm{Ru} \mathrm{K}$-edge region of the rutile-type $\mathrm{Cr}_{0.6} \mathrm{Ru}_{0.4} \mathrm{O}_{2}(550)$. Pure $\mathrm{Ru}$ metal foil and $\mathrm{RuO}_{2}$ powder were also measured as reference. The shoulder near the adsorption threshold of $\mathrm{Ru}$ foil is corresponding to the $1 s$ to $4 d$ transition. For $\mathrm{RuO}_{2}$ and $\mathrm{Cr}_{0.6} \mathrm{Ru}_{0.4} \mathrm{O}_{2}(550)$, this shoulder is weaker, because the increased lattice symmetry prevents the mixing of $4 d$ and $5 p$ orbitals. The observed transition energy of XANES (corresponding to the $1 s$ to $5 p$ transition) for $\mathrm{RuO}_{2}$ and $\mathrm{Cr}_{0.6} \mathrm{Ru}_{0.4} \mathrm{O}_{2}$ is higher than that for $\mathrm{Ru}$. This can be attributed to the formation of $\mathrm{Ru}-\mathrm{O}$ bonds, which pushes up the empty state of $5 p$ oribials of $\mathrm{Ru}$ atoms $\mathrm{s}^{50}$. We further analyzed the absorption energy $\left(E_{0}\right.$, determined from the first maximum in the first-order derivative), which is proportional to the oxidation state of transition metals ${ }^{51,52}$. We found that the absorption energy for $\mathrm{Cr}_{0.6} \mathrm{Ru}_{0.4} \mathrm{O}_{2}(550)\left(E_{0}=22129.9 \mathrm{eV}\right)$ was similar with the value of $\mathrm{RuO}_{2}\left(E_{0}=22129.5 \mathrm{eV}\right)$, implying that the oxidation state of $\mathrm{Ru}$ in $\mathrm{Cr}_{0.6} \mathrm{Ru}_{0.4} \mathrm{O}_{2}(550)$ is close to +4 . The slightly higher absorption energy can be attributed to the electron withdrawing effect of the neighboring lattice $\mathrm{Cr}^{4+}$ ion, consistent with the XPS analysis results. Ru K-edge extended $\mathrm{X}$-ray absorption fine structure (EXAFS) analysis was used to reveal the initial information on the $\mathrm{Ru}-\mathrm{O}$ and $\mathrm{Ru}-\mathrm{Ru}$ bonds. The corresponding Fourier transformed (FT) radial structure based on the $k^{2}$-weighted EXAFS is displayed in Fig. 7c. The peak at $1.59 \AA$ for $\mathrm{RuO}_{2}$ is associated with the back scattering of $\mathrm{Ru}-\mathrm{O}$ in the first shell ${ }^{27}$. In contrast, the $\mathrm{Ru}-\mathrm{O}$ bond length in $\mathrm{Cr}_{0.6} \mathrm{Ru}_{0.4} \mathrm{O}_{2}(550)$ is slightly shortened to $1.55 \AA$, in line with the slightly higher absorption energy for $\mathrm{Cr}_{0.6} \mathrm{Ru}_{0.4} \mathrm{O}_{2}(550)$. The peaks at 2.73 and $3.21 \AA$ for $\mathrm{RuO}_{2}$ arise from the back scatterings of $\mathrm{Ru}-\mathrm{Ru}$ in the second and third shell ${ }^{53}$. These peaks for $\mathrm{Cr}_{0.6} \mathrm{Ru}_{0.4} \mathrm{O}_{2}(550)$ are assigned to the back scatterings $\mathrm{Ru}-\mathrm{Ru}$ and $\mathrm{Ru}-\mathrm{Cr}$. The decreased intensity (i.e., vibrational amplitude) should be ascribed to the extremely small particle size (less than $15 \mathrm{~nm})^{54,55}$. Furthermore, these peaks are also shifted to the left. Clearly, the presence of $\mathrm{Cr}$ can profoundly alter the local electronic structures of $\mathrm{Ru}$ and the associated $\mathrm{Ru}-\mathrm{O}$ bonding, which directly determine the OER activity. Accordingly, Cr Kedge XANES and EXAFS were also used to examine the $\mathrm{Cr}$ oxide state, and $\mathrm{Cr}-\mathrm{O}$ bond in $\mathrm{Cr}_{0.6} \mathrm{Ru}_{0.4} \mathrm{O}_{2}$ (550) (Fig. 7b, d). The absorption energy of $\mathrm{Cr}_{0.6} \mathrm{Ru}_{0.4} \mathrm{O}_{2}(550) \quad\left(E_{0}=6006.7 \mathrm{eV}\right)$ is higher than that of $\mathrm{Cr}$ metal $\left(E_{0}=5989.0 \mathrm{eV}\right)$, but close to the value of $\mathrm{CrO}_{2}\left(E_{0}=6006.8 \mathrm{eV}\right)$. In addition, the peak in the region of pre-edge absorption is also a characteristic of the formation of $\mathrm{Cr}^{4+}$, corresponding to the $1 s$ to $3 d$ transition $^{56}$. The slightly lower absorption energy can be attributed to the electron withdrawing effect of $\mathrm{Cr}^{4+}$ ion, in agreement with the XPS results and Ru oxidation analysis. In addition, as shown in Fig. $7 \mathrm{~d}$, the $\mathrm{Cr}-\mathrm{O}$ length for $\mathrm{CrO}_{2}$ is $1.47 \AA$. In $\mathrm{Cr}_{0.6} \mathrm{Ru}_{0.4} \mathrm{O}_{2}(550)$, the $\mathrm{Cr}-\mathrm{O}$ is slightly elongated to $1.50 \AA$, in accordance with the EXAFS result of $\mathrm{Ru}$ K-edge. For comparison, we also measured the $\mathrm{Cr}$ K-edge XANES of $\mathrm{Cr}_{0.6} \mathrm{Ru}_{0.4} \mathrm{O}_{2}$ (450). As shown in Supplementary Figure 31, the intensity of the pre-edge peak of $\mathrm{Cr}_{0.6} \mathrm{Ru}_{0.4} \mathrm{O}_{2}(450)$ is above that of $\mathrm{Cr}_{0.6} \mathrm{Ru}_{0.4} \mathrm{O}_{2}(550)$, indicating a lower symmetry environment of the $\mathrm{Cr}$ atoms in $\mathrm{Cr}_{0.6} \mathrm{Ru}_{0.4} \mathrm{O}_{2}(450)^{56}$. It confirmed that the fine structure of $\mathrm{Cr}_{0.6} \mathrm{Ru}_{0.4} \mathrm{O}_{2}(450)$ is different from that of $\mathrm{Cr}_{0.6} \mathrm{Ru}_{0.4} \mathrm{O}_{2}(550)$, i.e., the pure phase rutile $\mathrm{Cr}-\mathrm{Ru}$ oxide has not been well formed. 

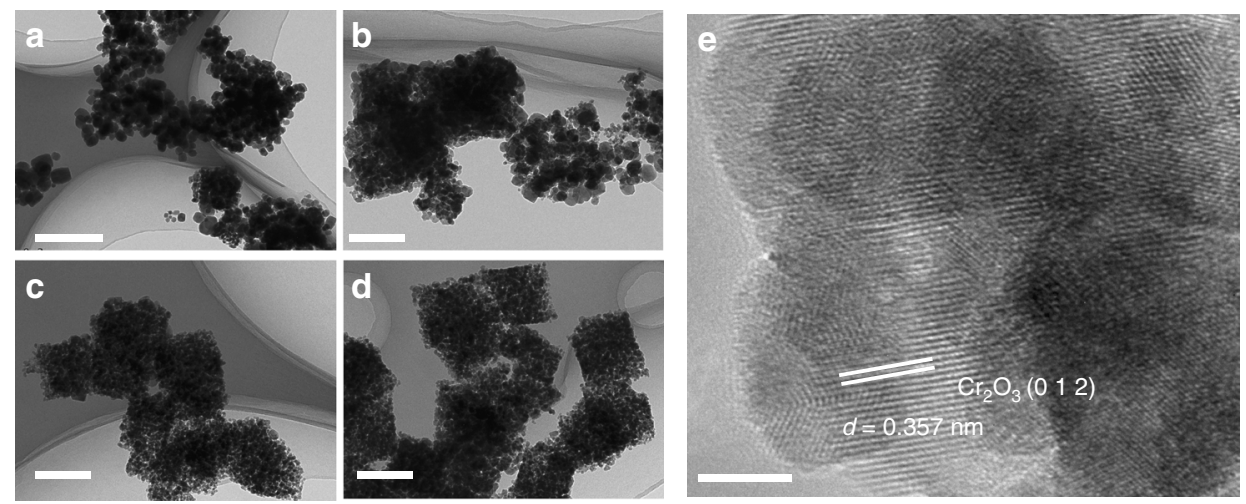

f
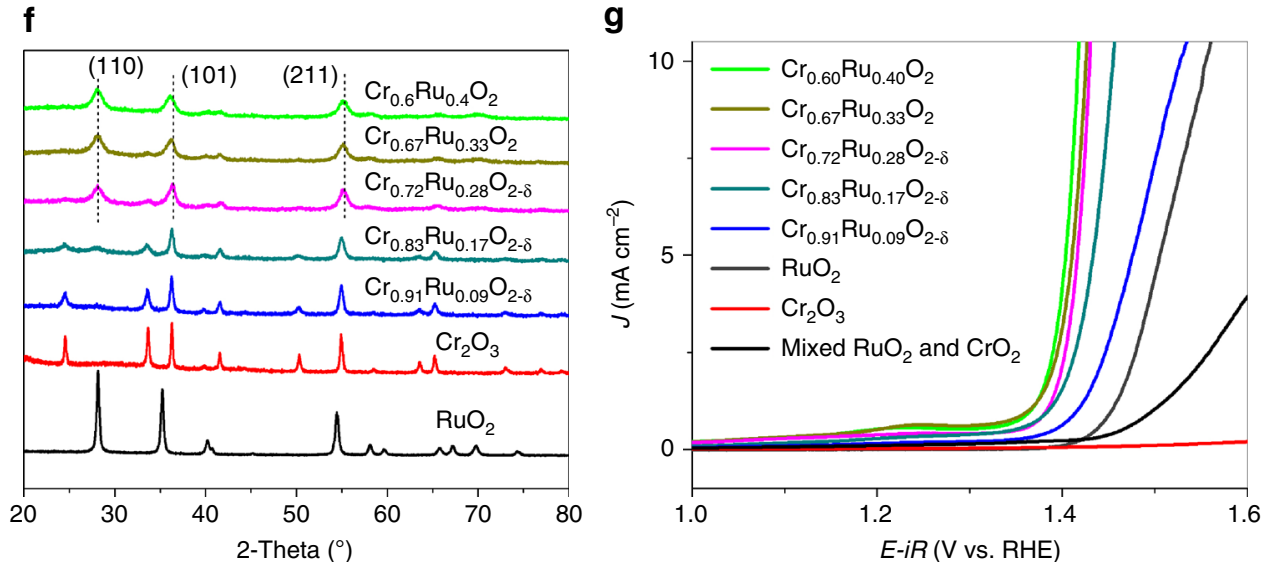

Fig. 5 Evolution of chromium-ruthenium oxides with different $\mathrm{Cr} / \mathrm{Ru}$ ratios: a-d TEM images of $\mathrm{Cr}_{0.91} \mathrm{Ru}_{0.09} \mathrm{O}_{2-\delta}, \mathrm{Cr}_{0.83} \mathrm{Ru}_{0.17} \mathrm{O}_{2-\delta}, \mathrm{Cr}_{0.72} \mathrm{Ru}_{0.28} \mathrm{O}_{2-\delta}$ and $\mathrm{Cr}_{0.67} \mathrm{Ru}_{0.33} \mathrm{O}_{2}$, respectively (scale bars, $200 \mathrm{~nm}$ ); e HR-TEM image of $\mathrm{Cr}_{0.83} \mathrm{Ru}_{0.17} \mathrm{O}_{2-\delta}$ (scale bar, $5 \mathrm{~nm}$ ); $\mathbf{f} \mathrm{PXRD}$ patterns, $\mathrm{Cr}_{2} \mathrm{O}_{3}$ powder was obtained from directly annealing pure MIL-101 (Cr); $\mathbf{g}$ LSV results
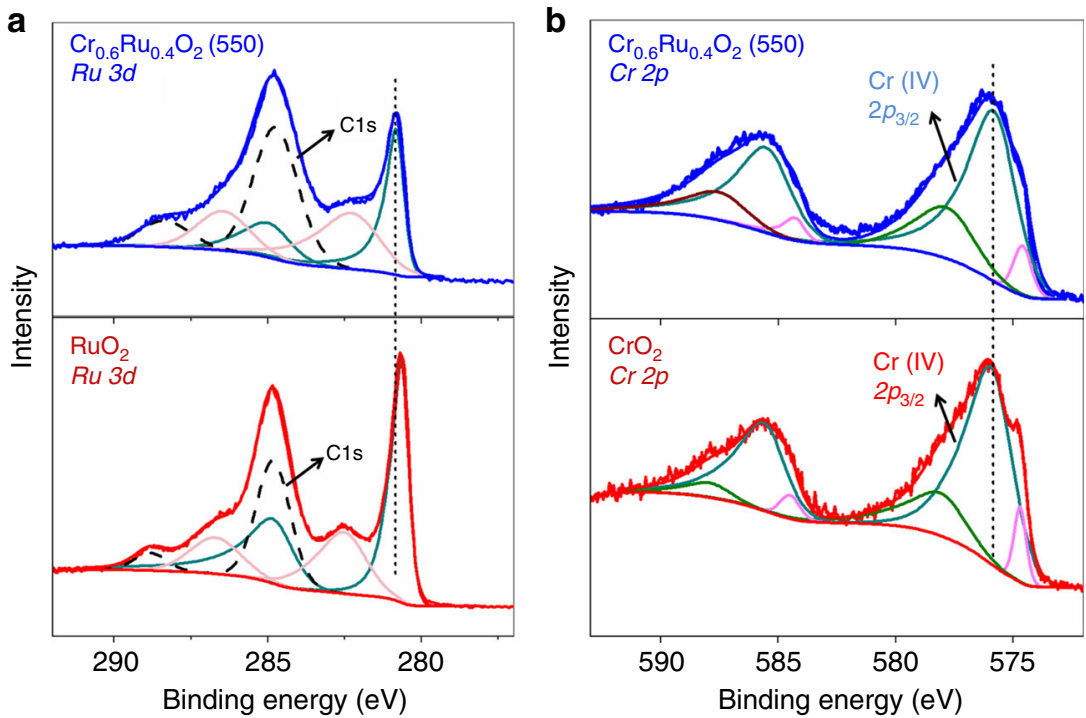

Fig. 6 XPS of $\mathrm{Cr}_{0.6} \mathrm{Ru}_{0.4} \mathrm{O}_{2}$ (550) for $\mathrm{Ru} 3 d$ and $\mathrm{Cr} 2 p$. a XPS of $\mathrm{Cr}_{0.6} \mathrm{Ru}_{0.4} \mathrm{O}_{2}(550)$ and $\mathrm{RuO}_{2}$ for Ru $3 d$ regions. b XPS of $\mathrm{Cr}_{0.6} \mathrm{Ru}_{0.4} \mathrm{O}_{2}(550)$ and $\mathrm{CrO}_{2}$ for $\mathrm{Cr} 2 p$ regions. The blue and red smoothing lines are fitting results of the sum of individual components. For Ru $3 d$, color codes are used to distinguish the different spin-orbit components, dark cyan for primary Ru $3 d_{3 / 2}$ and $3 d_{5 / 2}$ spin states, and light magenta for satellite Ru $3 d_{3 / 2}$ and $3 d_{5 / 2}$ spin states

Finally, we carried out DFT calculations in order to understand the promoted OER performance of $\mathrm{CrO}_{2}-\mathrm{RuO}_{2}$ electrocatalyst. Here we constructed a simulation model of $\mathrm{Cr}_{5} \mathrm{Ru}_{3} \mathrm{O}_{16}$, which has a composition close to the experimentally measured value. We assumed that $\mathrm{Cr}$ and $\mathrm{Ru}$ are distributed as evenly as possible in the rutile-like crystal. The simulated PXRD pattern of the relaxed structure was in good agreement with experiments. Based on the Bader charge analysis, the partial charge of $\mathrm{Ru}$ in bulk $\mathrm{RuO}_{2}$ was 

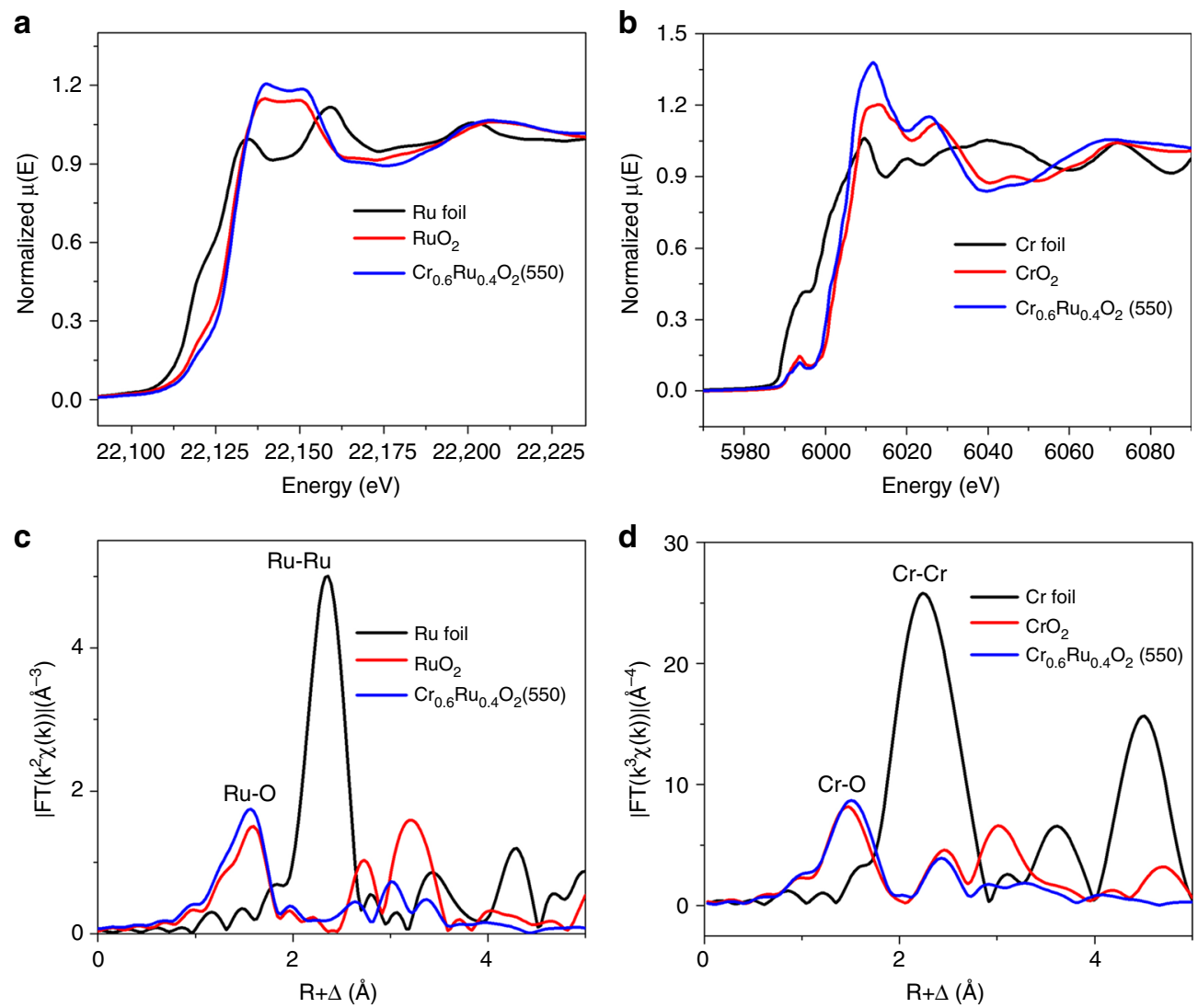

Fig. 7 XAS analysis of $\mathrm{Cr}_{0.6} \mathrm{Ru}_{0.4} \mathrm{O}_{2}$ (550) electrocatalyst. a Normalized Ru K-edge XANES spectra of $\mathrm{Cr}_{0.6} \mathrm{Ru}_{0.4} \mathrm{O}_{2}$ (550), Ru foil and commercial RuO b Normalized $\mathrm{Cr}$ K-edge XANES spectra of $\mathrm{Cr}_{0.6} \mathrm{Ru}_{0.4} \mathrm{O}_{2}(550), \mathrm{Cr}$ foil, and commercial $\mathrm{CrO}_{2}$. c Fourier transformed EXAFS spectra of Ru edge for $\mathrm{Cr}_{0.6} \mathrm{Ru}_{0.4} \mathrm{O}_{2}$ (550), Ru foil and commercial $\mathrm{RuO}_{2}$. d Fourier transformed EXAFS spectra of $\mathrm{Cr}$ edge for $\mathrm{Cr}_{0.6} \mathrm{Ru}_{0.4} \mathrm{O}_{2}(550), \mathrm{Cr}_{\text {foil, }}$ and commercial $\mathrm{CrO}_{2}$

calculated to be $+1.73|\mathrm{e}|$. For comparison, the $\mathrm{Ru}$ cation in $\mathrm{Cr}_{5} \mathrm{Ru}_{3} \mathrm{O}_{16}$ possesses a higher positive charge of $+1.92|\mathrm{e}|$. Accordingly, the partial charge on the neighboring $\mathrm{Cr}$ cation decreases from $+1.89|\mathrm{e}|$ in $\mathrm{CrO}_{2}$ to $+1.84|\mathrm{e}|$ in $\mathrm{Cr}_{5} \mathrm{Ru}_{3} \mathrm{O}_{16}$. Clearly, the electron transfer from $\mathrm{Ru}$ to $\mathrm{Cr}$ is consistent with the XANES results. More positively charged Ru cations lead to smaller cation radius, and the corresponding peaks in EXAFS slightly shift to the left. Moreover, the highly oxidized state of Ru implies the improved ability for the oxidation of water to oxygen, namely OER. We further plotted the density of states (DOS) to discern the nature of the electronic structures. As shown in Fig. 8a, the incorporation of $\mathrm{Cr}$ apparently altered the DOS of nonmagnetic $\mathrm{RuO}_{2}$. The occupation at the Fermi level decreases from 2.01 states $/\left(\mathrm{eV}^{*}\right.$ cell ${ }^{\star}$ spin $)$ in $\mathrm{RuO}_{2}$ to 1.07 states $/\left(\mathrm{eV}^{*}\right.$ cell ${ }^{*}$ spin) in the solid solution, indicating the stabilization of crystalline structure ${ }^{57}$. Owing to the localized nature of $\mathrm{O} p$ band, its band center is known as an effective descriptor to predict intrinsic OER activity of oxides ${ }^{58}$. Considering the less electron number of $\mathrm{Cr}^{4+}\left(2 \mathrm{e}^{-}\right)$than that of $\mathrm{Ru}^{4+}\left(4 \mathrm{e}^{-}\right)$, the Fermi level of solid solution is shifted downward due to the band filling effect. Correspondingly, the $\mathrm{O} p$-band center moves closer to the Fermi level in $\mathrm{Cr}_{5} \mathrm{Ru}_{3} \mathrm{O}_{16}(-2.48 \mathrm{eV})$, compared with the value of $-2.91 \mathrm{eV}$ in $\mathrm{RuO}_{2}$. Clearly, the upshift $\mathrm{O} p$-band suggests the enhanced activity for OER. The detailed projected DOS of $\mathrm{Cr}_{5} \mathrm{Ru}_{3} \mathrm{O}_{16}$ are displayed in Supplementary Figures 32-33, also consistent with previous theoretical study on $\mathrm{CrO}_{2}-\mathrm{RuO}_{2}$ structures $^{59}$. The oxygen $2 p(\mathrm{O}-p)$ states below $\sim 1.5 \mathrm{eV}$ overlap with part of the metal $d$-bands. Metal $t_{2 g}$ orbitals show a unique spread and strong peak at the edge of valence band, especially in $\mathrm{Ru} d$-orbitals. Interestingly, the $\mathrm{O}-p$ orbital (the major component is below $-2 \mathrm{eV}$ ) and $\mathrm{Ru}-d$ bands at higher energy state are well separated in $\mathrm{RuO}_{2}$ (Fig. 8a). In contrast, the relatively low energy $\mathrm{Cr}_{2 \mathrm{~g}}$ orbitals can enhance the hybridization of O- $p$ orbital, thus further push $\mathrm{O} p$-center closer to Fermi level in the solid solution. Note that the empty $e_{\mathrm{g}}$ orbitals of $\mathrm{Cr}$ intensely strengthen the DOS ranging from about 2 to $6 \mathrm{eV}$ and the increased DOS related to $\sigma$ antibonding state suggests a weak $\mathrm{Cr}-\mathrm{O}$ binding strength.

On the other hand, we also calculated the free energy profiles of OER to directly compare the OER activities of $\mathrm{RuO}_{2}$ and $\mathrm{CrO}_{2}-\mathrm{RuO}_{2}$ solid solution. A slab model containing $32 \mathrm{O}$ and 16 metal atoms was employed, in which the $\mathrm{Cr} / \mathrm{Ru}$ ratio was kept as 5:3. Here we considered a four-step OER mechanism with CHE model to provide a general view ${ }^{60-62}$. We first focused on the (110) facet as the surface model, because it has been identified as the most stable from calculation of surface energy (Supplementary Table 8). We constructed surfaces of both $\mathrm{RuO}_{2}$ and solid solution for comparison. Five different configurations of solid solution surface were further modeled to average the calculated energy barriers. As shown in Fig. 8b, the five-coordinated surface $\mathrm{Ru}$ was identified as the reactive adsorption site. Interestingly, under the oxidation condition in water, the Ru site could readily adsorb $\mathrm{OH}$ to form ${ }^{*} \mathrm{OH}$. For all the models, the formation of ${ }^{\star} \mathrm{OOH}$ was found to be the rate determining step (RDS). On the $\mathrm{Cr}_{5} \mathrm{Ru}_{3} \mathrm{O}_{16}$ surface, the free energy change of $\mathrm{RDS}$ at the $\mathrm{Ru}$ site was calculated to be $1.87 \mathrm{eV}$, which is approximately $0.1 \mathrm{eV}$ lower than that on $\mathrm{RuO}_{2}$ surface $(2.02 \mathrm{eV})$ (Fig. 8c). It is consistent with the decreased overpotential of $100 \mathrm{mV}$ measured in experiments. To further corroborate the synergistic effect of $\mathrm{Cr}$ ions on the enhanced OER activity, we considered two more cases with 
a

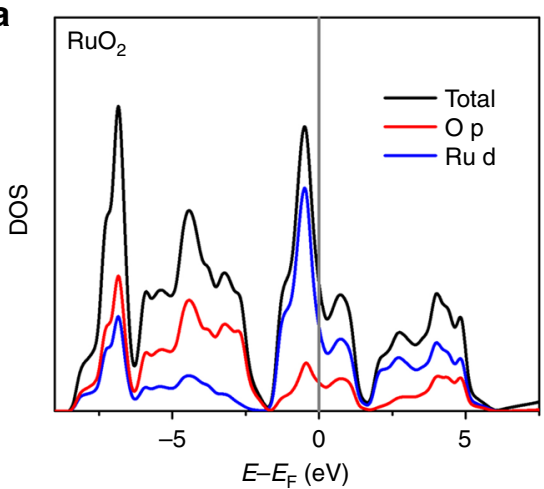

b

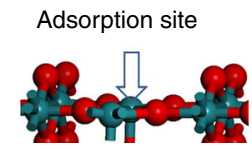

(110)

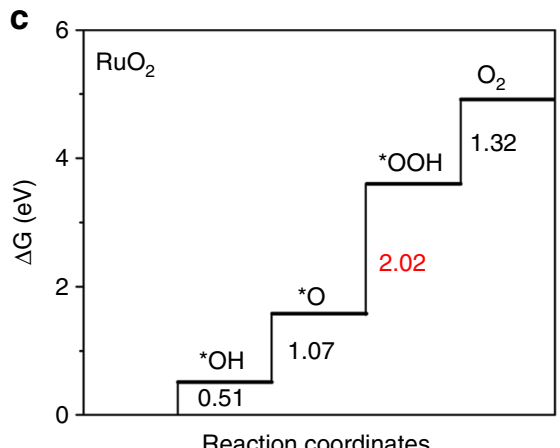

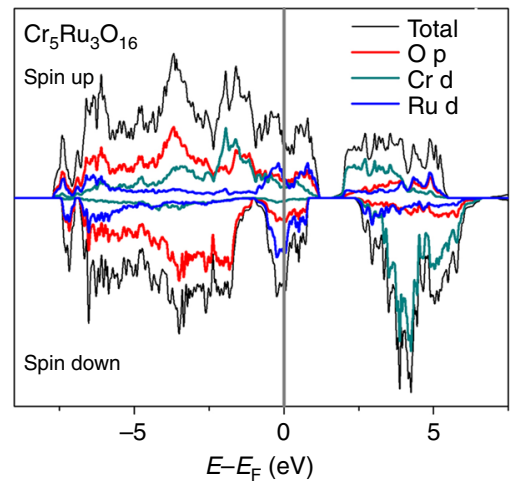
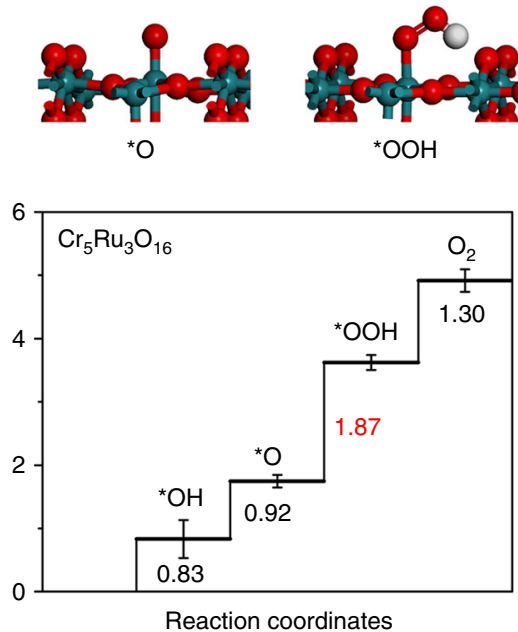

Fig. 8 DFT calculations on the studied $\mathrm{CrO}_{2}-\mathrm{RuO}_{2}$ solid solution system. a DOS of $\mathrm{RuO}_{2}$ and $\mathrm{Cr}_{5} \mathrm{Ru}_{3} \mathrm{O}_{16}$; b The four-step OER process; c The calculated free energy diagrams for $\mathrm{RuO}_{2}$ and $\mathrm{Cr}_{5} \mathrm{Ru}_{3} \mathrm{O}_{16}$

different $\mathrm{Ru}$ concentration and structures, as shown in Supplementary Figure 34. In the first one, there are only surface Ru and sub-surface $\mathrm{Cr}$ ions, in which the energy barrier for RDS was calculated to be $1.81 \mathrm{eV}$. In the second case, one $\mathrm{Cr}$ cation on $\mathrm{CrO}_{2}(110)$ surface was replaced by $\mathrm{Ru}$, yielding a reduced RDS barrier of $1.75 \mathrm{eV}$, which is lower than that of original $\mathrm{RuO} 2$ surface. On the other hand, we also investigated two relatively less stable surfaces, namely (200) and (101) facets, which were observed in HR-TEM image (Fig. $3 \mathrm{~d}$ ). In a previous experimental study ${ }^{63}$, these two surfaces of $\mathrm{RuO}_{2}$ were found to be more active. Our DFT results (Supplementary Figure 35) are consistent with this work, and the corresponding energy barriers of RDS on (200) and (101) surfaces were calculated to be 1.79 and $1.96 \mathrm{eV}$, respectively. In $\mathrm{CrO}_{2}-\mathrm{RuO}_{2}$ system, these two barriers were further decreased by 0.04 and $0.02 \mathrm{eV}$, respectively.

\section{Discussion}

In summary, by using Cr-based MOF, we have developed a cost effective rutile $\mathrm{Cr}_{0.6} \mathrm{Ru}_{0.4} \mathrm{O}_{2}$ electrocatalyst with superior OER activity and stability in acidic media. Our experimental results and DFT calculations revealed the profound influence of $\mathrm{Cr}$ on the OER performance. The enhanced stability is related to the lower occupation at the Fermi level, while the higher activity results from the altered electronic structures. The calculated free energy diagrams for OER further demonstrates a lower energy barrier for the formation of ${ }^{\star} \mathrm{OOH}$, which is the RDS. On the other hand, $\mathrm{Ru}$ plays the key role to induce the formation of ruile-structured $\mathrm{CrO}_{2}$ and thus $\mathrm{CrO}_{2}-\mathrm{RuO}_{2}$ solid solutions because $\mathrm{RuO}_{2}$ and $\mathrm{CrO}_{2}$ share the same rutile structure and have similar lattice constants. Note that direct annealing of the MIL-101(Cr) precursor only led to an inactive product of $\mathrm{Cr}_{2} \mathrm{O}_{3}$. These findings and results open a route to design highly active, stable and relatively low-cost electrocatalysts for OER in acidic media. To shed light on the further optimization, we have investigated and screened a series of possible rutile-like $\mathrm{MO}_{2}-\mathrm{RuO}_{2}$ systems, in which $\mathrm{M}$ is a tetravalent cation. In light of the altered electronic structures in $\mathrm{CrO}_{2}-\mathrm{RuO}_{2}$, we propose that the electron withdrawing on $\mathrm{Ru}$ ions can facilitate water oxidation and oxygen evolution. The calculated parameters of the cells and partial charges on $\mathrm{Ru}$ are summarized in Supplementary Table 9. It is noteworthy that the partial charge on Ru ions in $\mathrm{CrO}_{2}-\mathrm{RuO}_{2}$ is found to be the most positive. Interestingly, we found that $\mathrm{MnO}_{2}$ can also form solid solution with $\mathrm{RuO}_{2}$ and possess good OER performance, owing to the similar cell parameter with that of $\mathrm{RuO}_{2}$ and the highly positive partial charge on $\mathrm{Ru}(1.88 \mathrm{e})$. In contrast, we found that the reductive tetravalent cations, such as $\mathrm{Nb}$ and $\mathrm{W}$, lead to electron accumulation on $\mathrm{Ru}$. As a result, their corresponding solid solutions are expected to have lower OER activity. In addition to the formation of solid solution, we also anticipate that doping $\mathrm{RuO}_{2}$ with highly oxidizing metal ions, such as $\mathrm{Ce}^{4+}$, is another viable strategy to improve the OER activity. On the other hand, our preparation method for chromium ruthenium oxides solid solution electrocatalyst can be extended to prepare other rutile-structured electrocatalysts, such as the potentially active manganese ruthenium oxide and vanadium ruthenium oxide, or even non-Pt-group metal materials, such as chromium manganese oxide. 


\section{Methods}

Materials. All chemicals were obtained from commercial suppliers at analytical grade and used as received without further purification. The commercial $\mathrm{RuO}_{2}$ and $\mathrm{CrO}_{2}$ were purchased from Sigma-Aldrich.

MIL-101(Cr) synthesis. MIL-101(Cr) was prepared by a hydrothermal reaction following the procedure reported in our previously work ${ }^{30}$. The prepared MIL-101 (Cr) was activated at $150{ }^{\circ} \mathrm{C}$ under vacuum for $12 \mathrm{~h}$ for future use.

Preparation of $\mathbf{R u C l}_{\mathbf{3}}-\mathbf{M I L - 1 0 1}$ (Cr). A series of $\mathrm{RuCl}_{3}-\mathrm{MIL}-101$ (Cr) with different $\mathrm{RuCl}_{3}$ loading were prepared by mixing the desired amount of MIL-101 (Cr) and $\mathrm{RuCl}_{3}$ in THF solution. Typically, $0.2 \mathrm{~g} \mathrm{RuCl}_{3}$ was dissolved in $30 \mathrm{ml}$ tetrahydrofuran (THF) under stirring for $5 \mathrm{~min}$. After that, $0.2 \mathrm{~g}$ MIL-101 (Cr) was slowly added into the $\mathrm{RuCl}_{3}$ solution under stirring. To ensure the uniform distribution of $\mathrm{RuCl}_{3}$ within the pores and thus the formation of homogeneous $\mathrm{Cr}-\mathrm{Ru}$ oxide solid solution phase upon heating, the resulting mixture was further kept stirring at room temperature for $18 \mathrm{~h}$ to allow the compete loading of $\mathrm{RuCl}_{3}$ into MIL-101 (Cr) pores. After impregnation, the product was recovered by centrifugation, and washed four times with THF to remove $\mathrm{RuCl}_{3}$ remained on the outer surface of MIL-101 (Cr) particles. Finally, the resulting $\mathrm{RuCl}_{3}-\mathrm{MIL}-101(\mathrm{Cr})$ was dried at $80^{\circ} \mathrm{C}$ in air for $6 \mathrm{~h}$. For the other $\mathrm{RuCl}_{3}-\mathrm{MIL}-101(\mathrm{Cr})$ with lower $\mathrm{RuCl}_{3}$ loading, the amount of $\mathrm{RuCl}_{3}$ used was decreased to $0.15 \mathrm{~g}, 0.1 \mathrm{~g}, 0.05 \mathrm{~g}$, and $0.025 \mathrm{~g}$, respectively.

Preparation of $\mathbf{C r}_{\mathbf{1 - \mathbf { x }}} \mathbf{R u}_{\mathbf{x}} \mathbf{O}_{\mathbf{2}}$. Fifty microgram of $\mathrm{RuCl}_{3}-\mathrm{MIL}-101$ (Cr) powder was placed in muffle furnace and heated to $T\left(T=450,500,550,600,650^{\circ} \mathrm{C}\right)$ at a heating rate of $5{ }^{\circ} \mathrm{C} / \mathrm{min}$ and held for $4 \mathrm{~h}$. After cooling down to room temperatures, the resulting black products were collected, and denoted as $\mathrm{Cr}_{1-\mathrm{x}} \mathrm{Ru}_{\mathrm{x}} \mathrm{O}_{2}(\mathrm{~T})$.

Electrochemical measurements. In a typical procedure, $4 \mathrm{mg}$ of $\mathrm{Cr}_{1-\mathrm{x}} \mathrm{Ru}_{\mathrm{x}} \mathrm{O}_{2}$ was added to $1 \mathrm{ml}$ of water/ethanol $(3: 1, \mathrm{v} / \mathrm{v})$ containing $15 \mu \mathrm{l}$ Nafion aqueous solution (5\%, Sigma-Aldrich), and dispersed by sonication for $30 \mathrm{~min}$ to generate a homogeneous black ink. Five microliter of the catalyst ink was drop-cast on a glassy carbon electrode (surface area: $0.07065 \mathrm{~cm}^{2}$ ) and dried in air at room temperature to form a thin film working electrode. For the mixed $\mathrm{CrO}_{2}-\mathrm{RuO}_{2} / \mathrm{C}$ ink preparation, $4 \mathrm{mg}$ carbon black (commercial acetylene black that has high conductivity) was added. A three-electrode cell was employed to measure the OER electrochemical performance. The cell contained the glassy carbon working electrode, a counter electrode made of platinum wire (diameter: $0.5 \mathrm{~nm}$ ), and a saturated $\mathrm{Hg} / \mathrm{Hg}_{2} \mathrm{SO}_{4}$ reference electrode. All measurements were performed in $0.5 \mathrm{M}$ $\mathrm{H}_{2} \mathrm{SO}_{4}$ acidic solution after purging with $\mathrm{O}_{2}(99.999 \%)$ for at least $30 \mathrm{~min}$. The $\mathrm{Hg}$ / $\mathrm{Hg}_{2} \mathrm{SO}_{4}$ reference electrode was calibrated with a $\mathrm{Pt}$ wire electrode in $\mathrm{H}_{2}$-saturated $0.5 \mathrm{M} \mathrm{H}_{2} \mathrm{SO}_{4}$ solution. The potential difference between the $\mathrm{Hg} / \mathrm{Hg}_{2} \mathrm{SO}_{4}$ reference electrode and reversible hydrogen electrode is $0.645 \mathrm{~V}$. Cyclic voltammograms (CVs) tests were collected at a scan rate of $100 \mathrm{mV} / \mathrm{s}$ typically between 1.2 and 1.6 $\mathrm{V}$. Linear sweep voltammetry (LSV) curves were recorded at a scan rate of $5 \mathrm{mV} / \mathrm{s}$ typically between 0.8 and $1.6 \mathrm{~V}$. Chronopotentiometric measurements were conducted by applying constant current $\left(10 \mathrm{~mA} \mathrm{~cm}^{-2}\right)$ for up to $10 \mathrm{~h}$. Electrochemical impedance spectroscopy (EIS) were performed at $0.75 \mathrm{~V}$. The EIS results were presented in the form of Nyquist plot and fitted using ZView software with a representative equivalent electrical circuit.

Electrochemically active surface area (ECSAs). The ECSAs were estimated from the electrochemical double-layer capacitance of the catalytic surface. The double layer capacitance $\left(C_{\mathrm{DL}}\right)$ was determined by measuring the non-Faradaic capacitive current charging from the scan-rate dependence of CVs. The potential window of CVs was $1.21-1.31 \mathrm{~V}$ vs. RHE ( $0.1 \mathrm{~V}$ potential window centered at the open-circuit potential of the system). The $C_{\mathrm{DL}}$ was given by the following equation:

$$
i_{\mathrm{c}}=\nu \mathrm{C}_{\mathrm{DL}} \text {, }
$$

where $v$ is the scan rate. The slope of the plot of $i_{\mathrm{c}}$ as a function of $v$ is equal to $C_{\mathrm{DL}}$. The ECSA is calculated from the double layer capacitance according to:

$$
\mathrm{ECSA}=C_{\mathrm{DL}} / C_{\mathrm{s}},
$$

where $C_{\mathrm{s}}$ is the specific capacitance of the sample. We use general specific capacitances of $C_{\mathrm{s}}=0.035 \mathrm{mF} \mathrm{cm}^{-2}$ based on typical reported values. The roughness factor (RF) is then calculated by dividing ECSA by $0.07065 \mathrm{~cm}^{2}$, the geometric area of the electrode.

Material characterization. Power X-ray diffractions (PXRD) patterns of the samples were collected on a D8-Advance Bruker AXS diffractometer with $\mathrm{Cu}_{\mathrm{ka}}(\lambda$ $=1.5418 \AA$ ) radiation at room temperature. In order to obtain high quality data for $\mathrm{Cr}_{0.6} \mathrm{Ru}_{0.4} \mathrm{O}_{2}$ (550), a very slow scan measurement was performed with a scan interval of $0.005^{\circ}$ per step and a scan rate of $3 \mathrm{~s}$ per step. Structure analysis was conducted on Jade 2004. The lattice parameters were refined using GSAS software [A. C. Larson and R.B. von Dreele, Los Alamos, 1994]. Inductively coupled plasmamass spectroscopy (ICP-MS) measurements were carried on NexION 300 (Perkin-
Elmer). For the leaching measurements, the loading amounts of catalysts varied from 20 to $60 \mu \mathrm{g}$ and the volume of the electrolyte was $100 \mathrm{ml}$. After 10,000 cycles, the electrolyte was concentrated to a final volume of $\sim 10 \mathrm{ml}$ for ICP-MS analysis. The samples morphologies were examined using a field emission scanning electron microscope (SEM) (Hitachi, S-4800). SEM specimens were prepared by depositing sample powders on carbon adhesive tape on a SEM holder. Transmission electron microscopy (TEM) and high-resolution TEM (HR-TEM) images were recorded on Tecnai F20 microscope, and high-angle annular dark-field scanning transmission electron microscopy (HAADF-STEM) images were carefully recorded on Talos F200X and JEM-ARM200F. Atomic solution HAADF-STEM images were carefully recorded on JEM-ARM200F. For TEM specimen preparation, sample powders were firstly dispersed in ethanol by sonication, followed by dripping onto a carboncoated copper grid. Nitrogen adsorption/desorption isotherms were measured on ASAP2020M apparatus at $77 \mathrm{~K}$. The Brunauer-Emmett-Teller (BET) surface area was calculated over the range of relative pressures between 0.05 and 0.2 . Before the measurements were performed, the samples were outgassed under vacuum at $160^{\circ}$ $\mathrm{C}$ for $12 \mathrm{~h}$. X-ray photoelectron spectroscopy (XPS) spectra were recorded on the AXIS ULTRA using $\mathrm{Al}_{\mathrm{Ka}}$ radiation. The X-ray absorption data (XAS) at the $\mathrm{Ru}-\mathrm{K}$ edge and the $\mathrm{Cr} \mathrm{K}$ edge of the samples, which were mixed with $\mathrm{LiF}$ to reach $50 \mathrm{mg}$, were recorded at room temperature in transmission mode using ion chambers using the BL14W1 beam line of the Shanghai Synchrotron Radiation Facility (SSRF), China. The station was operated with a Si (111) double crystal monochromator. The electron beam energy of the storage ring was $3.5 \mathrm{GeV}$ and the maximum stored current was $\sim 210 \mathrm{~mA}$. The energy calibrations were performed using a Ru foil $(22117 \mathrm{eV})$ or $\mathrm{Cr}$ foil $(5989 \mathrm{eV})$. For Ru K-edge XAS, The extracted EXAFS signal, $\chi(\mathrm{k})$, was weighted by $k^{2}$ in k-range from 3.8 to $15.6 \AA^{-1}$ to obtain the magnitude. For Cr K-edge XAS, The extracted EXAFS signal, $\chi(\mathrm{k})$, was weighted by $k^{3}$ in k-range from 3 to $12 \AA^{-1}$ to obtain the magnitude.

Turnover frequency calculation (TOF). TOF was calculated based on the method reported in previous works ${ }^{27,40}$. This calculation assumes $100 \%$ Faradaic efficiency:

$$
\mathrm{TOF}=N_{\mathrm{O} 2} / N_{\mathrm{Ru}}
$$

where $\mathrm{N}_{\mathrm{O} 2}$ is the number of $\mathrm{O}_{2}$ turnovers, calculated using the following formula:

$$
\begin{gathered}
N_{\mathrm{O} 2}=\left(\mathrm{j} \mathrm{mA} \mathrm{cm}^{-2}\right) \times\left(\mathrm{A} \mathrm{cm}_{\text {oxide }}^{2}\right) \times\left(1 \mathrm{Cs}^{-1} / 1000 \mathrm{~mA}\right) \times \\
\left(1 \mathrm{~mol} \mathrm{e}^{-} / 96485 \mathrm{C}\right) \times\left(1 \mathrm{~mol} \mathrm{O}_{2} / 4 \mathrm{~mol} \mathrm{e}^{-}\right) \times N_{\mathrm{A}} .
\end{gathered}
$$

where $j$ is the measured current density, $A$ is the surface area of electrode, and $N_{\mathrm{A}}$ is Avogadro constant $\left(6.02 \times 10^{23} \mathrm{~mol}^{-1}\right)$.

The number of Ru sites $\left(\mathrm{N}_{\mathrm{Ru}}\right)$ is calculated using the formula: $\left(0.4 \times\left(20 \times 10^{-6}\right.\right.$ g) $\times N_{\mathrm{A}} /$ molecular weight of $\left.\mathrm{Cr}_{0.6} \mathrm{Ru}_{0.4} \mathrm{O}_{2}\right)$ for $\mathrm{Cr}_{0.6} \mathrm{Ru}_{0.4} \mathrm{O}_{2}$, and $\left(\left(20 \times 10^{-6} \mathrm{~g}\right) \times\right.$ $N_{\mathrm{A}} /$ molecular weight $\mathrm{RuO}_{2}$ ) for $\mathrm{RuO}_{2}$, respectively.

Density functional theory (DFT) calculations. The DFT calculations were performed using the Vienna Ab-initio Simulation Package (VASP) ${ }^{64}$. The PerdewBurke-Ernzerhof (PBE) functional of the generalized gradient approximation $(\mathrm{GGA})^{65}$ was employed with projector augmented wave (PAW) ${ }^{66}$ method. The valence electronic configurations were $\mathrm{O}(2 s, 2 p), \mathrm{Ru}(4 p, 4 d, 5 s), \mathrm{Cr}(3 p, 3 d, 4 s)$, and $\mathrm{H}(1 \mathrm{~s})$. In particular, the $U_{\text {eff }}$ of $3.7 \mathrm{eV}$ was utilized for $3 d$ orbital of Cr. Spin polarization was also considered. The energy cutoff for plane wave was set to 500 $\mathrm{eV}$. The thresholds for electronic structure iteration and geometry relaxation were $10^{-5} \mathrm{eV}$ and $0.03 \mathrm{eV} / \AA \AA$ in force, respectively. Due to the conducting nature, the first order Methfessel-Paxton method with smearing of $0.1 \mathrm{eV}$ was applied for optimization and tetrahedron method with Blöchl corrections was further used for the density of states (DOS) calculation. The lattices of $\mathrm{RuO}_{2}$ and $\mathrm{Cr}$ and Ru oxides solid solution were relaxed based on fixed rutile symmetry. $9 \times 9 \times 13$ MonkhorstPack k-point grid was used to sample the Brillouin zone. Then four layered (110) facet was cleaved with the vacuum slab height of $20 \AA$. A $2 \times 1$ supercell containing $32 \mathrm{O}$ and 16 metal atoms were studied with $5 \times 5 \times 1$ Monkhorst-Pack k-point grid. To describe vdW interaction, empirical Grimme's D3 correction was adopted.

The free energy of each species was calculated based on the following formula:

$$
G=E_{\mathrm{dft}}+E_{\mathrm{zpe}}-\mathrm{T} \Delta \mathrm{S}
$$

The zero-point energy and entropy correction were obtained from standard vibrational calculation, whereas the free energy of $\mathrm{O}_{2}$ was derived according to experimental standard formation energy of liquid water:

$$
\mathrm{G}\left(\mathrm{O}_{2}\right)=4.92 \mathrm{eV}+2 \mathrm{G}\left(\mathrm{H}_{2} \mathrm{O}\right)-2 \mathrm{G}\left(\mathrm{H}_{2}\right)
$$

Moreover, we have also attempted to screen a series of potential solid solutions for further prediction, which are composed of $\mathrm{RuO}_{2}$ and other rutile-like oxides, including $\mathrm{TiO}_{2}, \mathrm{VO}_{2}, \mathrm{CrO}_{2}, \mathrm{MnO}_{2}, \mathrm{GeO}_{2}, \mathrm{NbO}_{2}, \mathrm{MoO}_{2}, \mathrm{RhO}_{2}, \mathrm{SnO}_{2}, \mathrm{WO}_{2}$, and $\mathrm{PbO}_{2}$. The cell sizes of the bulk models were allowed to relax in the calculations at the aforementioned level. The calculated theoretical lattice parameters are listed in Supplementary Table 9. Ideally, the closer cell parameters for the two $\mathrm{MO}_{2}$ crystals, the higher possibility the solid solution can be formed. Besides, the atomic charges 
on Ru atoms in these solid solution systems were calculated based on the Bader charge analysis. Here the higher positive partial charge compared with Ru in bulk $\mathrm{RuO}_{2}$ indicates that the $\mathrm{Ru}$ ion in solid solution would donate electrons to other metals, and accordingly its oxidizing ability is strengthened to promote OER performance. For comparison, the number of valence electron and electronegativity of various metals are labeled in Supplementary Table 9. However, it seems that they have trivial influence on the electronic distribution on $\mathrm{Ru}$.

\section{Data availability}

The authors declare that all the published data supporting the findings of this study are available within the article and its supplementary information files.

Received: 22 March 2018 Accepted: 14 December 2018

Published online: 11 January 2019

\section{References}

1. Suen, N. T. et al. Electrocatalysis for the oxygen evolution reaction: recent development and future perspectives. Chem. Soc. Rev. 46, 337-365 (2017).

2. Seh, Z. W. et al. Combining theory and experiment in electrocatalysis: Insights into materials design. Science 355, eaad4998 (2017).

3. Liu, J., Zhu, D., Guo, C., Vasileff, A. \& Qiao, S.-Z. Design strategies toward advanced MOF-derived electrocatalysts for energy-conversion reactions. $A d v$. Energy Mater. 7, 1700518 (2017).

4. Smith, R. D. L., Prevot, M. S., Fagan, R. D., Trudel, S. \& Berlinguette, C. P. Water oxidation catalysis: electrocatalytic response to metal stoichiometry in amorphous metal oxide films containing iron, cobalt, and nickel. J. Am. Chem. Soc. 135, 11580-11586 (2013).

5. Subbaraman, R. et al. Trends in activity for the water electrolyser reactions on 3d M(Ni,Co,Fe,Mn) hydr(oxy)oxide catalysts. Nat. Mater. 11, 550 (2012).

6. Guan, B. Y., Yu, L. \& Lou, X. W. General synthesis of multishell mixed-metal oxyphosphide particles with enhanced electrocatalytic activity in the oxygen evolution reaction. Angew. Chem. Int. Ed. 56, 2386-2389 (2017).

7. $\mathrm{Li}, \mathrm{M}$. et al. Facile synthesis of electrospun $\mathrm{MFe}_{2} \mathrm{O}_{4}(\mathrm{M}=\mathrm{Co}, \mathrm{Ni}, \mathrm{Cu}, \mathrm{Mn})$ spinel nanofibers with excellent electrocatalytic properties for oxygen evolution and hydrogen peroxide reduction. Nanoscale 7, 8920-8930 (2015).

8. Matsumoto, Y., Yamada, S., Nishida, T. \& Sato, E. Oxygen evolution on $\mathrm{La}_{1-\mathrm{x}}$ $\mathrm{Sr}_{\mathrm{x}} \mathrm{Fe}_{1-\mathrm{y}} \mathrm{Co}_{\mathrm{y}} \mathrm{O}_{3}$ series oxides. J. Electrochem. Soc. 127, 2360-2364 (1980).

9. $\mathrm{Lu}, \mathrm{Z}$. et al. Electrochemical tuning of layered lithium transition metal oxides for improvement of oxygen evolution reaction. Nat. Commun. 5, 4345 (2014).

10. Burke, M. S., Kast, M. G., Trotochaud, L., Smith, A. M. \& Boettcher, S. W. Cobalt-Iron(oxy)hydroxide oxygen evolution electrocatalysts: the role of structure and composition on activity, stability, and mechanism. J. Am. Chem. Soc. 137, 3638-3648 (2015).

11. Sardar, K. et al. Water-splitting electrocatalysis in acid conditions using ruthenate-iridate pyrochlores. Angew. Chem. Int. Ed. 53, 10960-10964 (2014).

12. Carmo, M., Fritz, D. L., Merge, J. \& Stolten, D. A comprehensive review on PEM water electrolysis. Int. J. Hydrog. Energy 38, 4901-4934 (2013).

13. Park, S., Shao, Y. Y., Liu, J. \& Wang, Y. Oxygen electrocatalysts for water electrolyzers and reversible fuel cells: status and perspective. Energy Environ. Sci. 5, 9331-9344 (2012).

14. Lee, Y., Suntivich, J., May, K. J., Perry, E. E. \& Shao-Horn, Y. Synthesis and activities of rutile $\mathrm{IrO}_{2}$ and $\mathrm{RuO}_{2}$ nanoparticles for oxygen evolution in acid and alkaline solutions. J. Phys. Chem. Lett. 3, 399-404 (2012).

15. McCrory, C. C. L. et al. Benchmarking hydrogen evolving reaction and oxygen evolving reaction electrocatalysts for solar water splitting devices. J. Am. Chem. Soc. 137, 4347-4357 (2015).

16. Rao, R. R. et al. Towards identifying the active sites on $\mathrm{RuO}_{2}(110)$ in catalyzing oxygen evolution. Energy Environ. Sci. 10, 2626-2637 (2017).

17. Kotz, R., Lewerenz, H. J. \& Stucki, S. XPS studies of oxygen evolution on Ru and $\mathrm{RuO}_{2}$ anodes. J. Electrochem. Soc. 130, 825-829 (1983).

18. Trasatti, S. Electrocatalysis in the anodic evolution of oxygen and chlorine. Electrochim. Acta 29, 1503-1512 (1984).

19. Marshall, A. T. \& Haverkamp, R. G. Electrocatalytic activity of $\mathrm{IrO}_{2}-\mathrm{RuO}_{2}$ supported on Sb-doped $\mathrm{SnO}_{2}$ nanoparticles. Electrochim. Acta 55, 1978-1984 (2010).

20. Marshall, A. T., Sunde, S., Tsypkin, A. \& Tunold, R. Performance of a PEM water electrolysis cell using $\mathrm{Ir}_{\mathrm{x}} \mathrm{Ru}_{\mathrm{y}} \mathrm{Ta}_{\mathrm{z}} \mathrm{O}_{2}$ electrocatalysts for the oxygen evolution electrode. Int. J. Hydrog. Energy 32, 2320-2324 (2007).

21. Cheng, J. B., Zhang, H. M., Chen, G. B. \& Zhang, Y. N. Study of $\operatorname{Ir}_{\mathrm{x}} \mathrm{Ru}_{1-\mathrm{x}} \mathrm{O}_{2}$ oxides as anodic electrocatalysts for solid polymer electrolyte water electrolysis. Electrochim. Acta 54, 6250-6256 (2009).

22. Owe, L.-E., Tsypkin, M., Wallwork, K. S., Haverkamp, R. G. \& Sunde, S. Iridium-ruthenium single phase mixed oxides for oxygen evolution: composition dependence of electrocatalytic activity. Electrochim. Acta 70, 158-164 (2012)

23. Diaz-Morales, O. et al. Iridium-based double perovskites for efficient water oxidation in acid media. Nat. Commun. 7, 12363 (2016).

24. Nong, H. N. et al. Oxide-supported $\mathrm{IrNiO}_{\mathrm{x}}$ core-shell particles as efficient, cost-effective, and stable catalysts for electrochemical water splitting. Angew. Chem. Int. Ed. 54, 2975-2979 (2015).

25. Seitz, L. C. et al. A highly active and stable $\mathrm{IrOx} / \mathrm{SrIrO}_{3}$ catalyst for the oxygen evolution reaction. Science 353, 1011-1104 (2016).

26. Lebedev, D. et al. Highly active and stable iridium pyrochlores for oxygen evolution reaction. Chem. Mater. 29, 5182-5191 (2017)

27. Kim, J. et al. High-performance pyrochlore-type yttrium ruthenate electrocatalyst for oxygen evolution reaction in acidic media. J. Am. Chem. Soc. 139, 12076-12083 (2017).

28. Zhang, L. J. et al. Highly graphitized nitrogen-doped porous carbon nanopolyhedra derived from ZIF-8 nanocrystals as efficient electrocatalysts for oxygen reduction reactions. Nanoscale 6, 6590-6602 (2014).

29. Ferey, G. et al. A chromium terephthalate-based solid with unusually large pore volumes and surface area. Science 309, 2040-2042 (2005).

30. Lin, Y. C., Yan, Q. J., Kong, C. L. \& Chen, L. Polyethyleneimine incorporated metal-organic frameworks adsorbent for highly selective $\mathrm{CO}_{2}$ capture. Sci. Rep. 3, 1859 (2013).

31. Chowdhury, P., Bikkina, C. \& Gumma, S. Gas adsorption properties of the chromium-based metal organic framework MIL-101. J. Phys. Chem. C 113, 6616 (2009)

32. Li, B. Y. et al. Capture of organic iodides from nuclear waste by metal-organic framework-based molecular traps. Nat. Commun. 8, 485 (2017).

33. McCrory, C. C., Jung, S., Peters, J. C. \& Jaramillo, T. F. Benchmarking heterogeneous electrocatalysts for the oxygen evolution reaction. J. Am. Chem. Soc. 135, 16977-16987 (2013).

34. Sun, W. et al. Effect of lattice strain on the electro-catalytic activity of $\mathrm{IrO}_{2}$ for water splitting. Chem. Commun. 54, 996-999 (2018).

35. Audichon, T. et al. $\mathrm{IrO}_{2}$ coated on $\mathrm{RuO}_{2}$ as efficient and stable electroactive nanocatalysts for electrochemical water splitting. J. Phys. Chem. C 120, 2562-2573 (2016).

36. Harrington, D. A. \& van den Driessche, P. Mechanism and equivalent circuits in electrochemical impedance spectroscopy. Electrochim. Acta 56, 8005-8013 (2011).

37. Hu, J. M., Zhang, J. Q. \& Cao, C. N. Oxygen evolution reaction on $\mathrm{IrO}_{2}$-based DSA (R) type electrodes: kinetics analysis of Tafel lines and EIS. Int. J. Hydrog. Energy 29, 791-797 (2004).

38. Li, G., Li, S., Ge, J., Liu, C. \& Xing, W. Discontinuously covered $\mathrm{IrO}_{2}-\mathrm{RuO}_{2} @ \mathrm{Ru}$ electrocatalysts for the oxygen evolution reaction: how high activity and longterm durability can be simultaneously realized in the synergistic and hybrid nano-structure. J. Mater. Chem. A 5, 17221-17229 (2017).

39. Gao, M. R. et al. Nitrogen-doped graphene supported $\mathrm{CoSe}_{2}$ nanobelt composite catalyst for efficient water oxidation. ACS Nano 8, 3970-3978 (2014).

40. Ng, J. W. D. et al. Gold-supported cerium-doped NiOx catalysts for water oxidation. Nat. Energy 1, 16053 (2016).

41. Shen, X. Q., Xiang, J., Song, F. Z. \& Liu, M. Q. Characterization and magnetic properties of electrospun $\mathrm{Co}_{1-x} \mathrm{Zn}_{x} \mathrm{Fe}_{2} \mathrm{O}_{4}$ nanofibers. Appl. Phys. A 99, 189-195 (2010).

42. Ryoken, $\mathrm{H}$. et al. Structures and properties of $(\mathrm{Zn}, \mathrm{Mg}) \mathrm{O}$ films studied from the aspect of phase equilibria. J. Cryst. Growth 287, 134-138 (2006).

43. Morgan, D. J. Resolving ruthenium: XPS studies of common ruthenium materials. Surf. Interface Anal. 47, 1072-1079 (2015).

44. Sarma, D. D. \& Rao, C. N. R. XPES studies of oxides of 2nd-row and 3rd-row transition-metals including rare-earths. J. Electron Spectrosc. Relat. Phenom. 20, 25-45 (1980).

45. Shen, J. Y., Adnot, A. \& Kaliaguine, S. An ESCA study of the interaction of oxygen with the surface of ruthenium. Appl. Surf. Sci. 51, 47-60 (1991).

46. Cheng, R. H. et al. Characterization of the native $\mathrm{Cr}_{2} \mathrm{O}_{3}$ oxide surface of $\mathrm{CrO}_{2}$ Appl. Phys. Lett. 79, 3122-3124 (2001).

47. Mao, L. Q. et al. The role of temperature on $\mathrm{Cr}(\mathrm{VI})$ formation and reduction during heating of chromium-containing sludge in the presence of $\mathrm{CaO}$. Chemosphere 138, 197-204 (2015).

48. Agostinelli, E., Battistoni, C., Fiorani, D. \& Mattogno, G. An XPS study of the electronic-structure of the $\mathrm{Zn}_{\mathrm{x}} \mathrm{Cd}_{1-\mathrm{x}} \mathrm{Cr}_{2} \mathrm{~S}_{4} \mathrm{Zn}_{\mathrm{x}} \mathrm{Cd}_{1-\mathrm{x}} \mathrm{Cr}_{2} \mathrm{Se}_{4}$ spinel system. J. Phys. Chem. Solids 50, 269-272 (1989).

49. Halada, G. P. \& Clayton, C. R. Photoreduction of hexavalent chromium during X-ray photoelectron-spectroscopy analysis of electrochemical and thermal films. J. Electrochem. Soc. 138, 2921-2927 (1991).

50. Chen, T.-Y. et al. Heterojunction confinement on the atomic structure evolution of near monolayer core-shell nanocatalysts in redox reactions of a direct methanol fuel cell. J. Mater. Chem. A 3, 1518-1529 (2015).

51. Arčon, I., Benčan, A., Kodre, A. \& Kosec, M. X-ray absorption spectroscopy analysis of $\mathrm{Ru}_{\text {in }} \mathrm{La}_{2} \mathrm{RuO}_{5}$. X-Ray Spectrom. 36, 301-304 (2007). 
52. Wong, J., Lytle, F. W., Messmer, R. P. \& Maylotte, D. H. X-edge absorption spectra of selected vanadium compounds. Phys. Rev. B 30, 5996-5610 (1984).

53. $\mathrm{Hu}, \mathrm{Y}$. Y. et al. Origin of additional capacities in metal oxide lithium-ion battery electrodes. Nat. Mater. 12, 1130-1136 (2013).

54. Marcus, M. A., Andrews, M. P. \& Zegenhagen, J. Structure and vibrations of chemically produced $\mathrm{Au}_{55}$ clusters,. Phys. Rev. B 42, 3312-3316 (1990).

55. Rockenberger, J. et al. EXAFS studies on the size dependence of structural and dynamic properties of CdS nanoparticles. J. Phys. Chem. B 101, 2691-2701 (1997).

56. Miyano, K. E., Woicik, J. C., Sujatha Devi, P. \& Gafney, H. D. Cr K edge X-ray absorption study of $\mathrm{Cr}$ dopants in $\mathrm{Mg}_{2} \mathrm{SiO}_{4}$ and $\mathrm{Ca}_{2} \mathrm{GeO}_{4}$. Appl. Phys. Lett. 71, 1168-1170 (1997).

57. Sorantin, P. I. \& Schwarz, K. Chemical bonding in rutile-type compounds. Inorg. Chem. 31, 567-576 (1992).

58. Grimaud, A. et al. Double perovskites as a family of highly active catalysts for oxygen evolution in alkaline solution. Nat. Commun. 4, 2439 (2013).

59. Chetry, K. B., Sims, H. \& Bulter, W. H. Electronic and magnetic structure of $\mathrm{CrO}_{2}-\mathrm{RuO}_{2}$ interfaces. Phys. Rev. B 84, 054438 (2011).

60. Rossmeisl, J., Logadottir, A. \& Norskov, J. K. Electrolysis of water on (oxidized) metal surfaces. Chem. Phys. 319, 178-184 (2005).

61. Ping, Y., Nielsen, R. J. \& Goddard, W. A. The reaction mechanism with free energy barriers at constant potentials for the oxygen evolution reaction at the $\mathrm{IrO}_{2}$ (110) surface. J. Am. Chem. Soc. 139, 149-155 (2017).

62. Chen, D., Fang, Y. H. \& Liu, Z. P. Searching for active binary rutile oxide catalyst for water splitting from first principles. Phys. Chem. Chem. Phys. 14, 16612-16617 (2012).

63. Stoerzinger, K. A. et al. Orientation-dependent oxygen evolution on $\mathrm{RuO}_{2}$ without lattice exchange. ACS Energy Lett. 2, 876-881 (2017).

64. Kresse, G. \& Furthmuller, J. Efficient iterative schemes for ab initio totalenergy calculations using a plane-wave basis set. Phys. Rev. B 54, 11169-11186 (1996).

65. Perdew, J. P., Burke, K. \& Ernzerhof, M. Generalized gradient approximation made simple. Phys. Rev. Lett. 77, 3865-3868 (1996).

66. Blochl, P. E. Projector augmented-wave method. Phys. Rev. B 50, 17953-17979 (1994).

67. Feng, J. et al. Iridium-based multimetallic porous hollow nanocrystals for efficient overall-water-splitting catalysis. Adv. Mater. 29, 1703798 (2017).

68. Kumari, S. et al. A low-noble-metal $\mathrm{W}_{1-\mathrm{x}} \mathrm{Ir}_{\mathrm{x}} \mathrm{O}_{3-\delta}$ water oxidation electrocatalyst for acidic media via rapid plasma synthesis. Energy Environ. Sci. 10, 2432-2440 (2017).

69. Pi, Y., Shao, Q., Wang, P., Guo, J. \& Huang, X. General formation of monodisperse IrM $(\mathrm{M}=\mathrm{Ni}, \mathrm{Co}, \mathrm{Fe})$ bimetallic nanoclusters as bifunctional electrocatalysts for acidic overall water splitting. Adv. Funct. Mater. 27, 1700886 (2017).

70. Zhang, J. et al. Iridium nanoparticles anchored on $3 \mathrm{D}$ graphite foam as a bifunctional electrocatalyst for excellent overall water splitting in acidic solution. Nano Energy 40, 27-33 (2017).

\section{Acknowledgements}

We thank Dr. Minghui Yang and Dr. Minghao Zhang for the help on the Rietveld refinement of $\mathrm{Cr}_{0.6} \mathrm{Ru}_{0.4} \mathrm{O}_{2}$ structure. We thank Dr. Haifeng Zhao for very helpful discussions on EXAFS results. This work was financially supported by National Science Foundation of China (Nos. 51472255 and 51602320), the aided program for science and technology innovative research team of Ningbo municipality (No. 2015B11002). This research used computational resources of the High-Performance Computing Center of Collaborative Innovation Center of Advanced Microstructures, Nanjing University.

\section{Author contributions}

L.C. and Y.L. designed the project and wrote the manuscript; Y.L. carried out the experiments; Z.T. carried out DFT calculations and wrote the computational part of manuscript; L.Z., J.M., and Z.J. performed the XANES and EXAFS experiments and data analysis. B.J.D. and R.G. provided helpful suggestions and polished the manuscript. All authors discussed the results and commented on the manuscript.

\section{Additional information}

Supplementary Information accompanies this paper at https://doi.org/10.1038/s41467018-08144-3.

Competing interests: The authors declare no competing interests.

Reprints and permission information is available online at http://npg.nature.com/ reprintsandpermissions/

Journal peer review information: Nature Communications thanks the anonymous reviewers for their contribution to the peer review of this work. Peer reviewer reports are available.

Publisher's note: Springer Nature remains neutral with regard to jurisdictional claims in published maps and institutional affiliations.

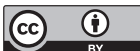

Open Access This article is licensed under a Creative Commons Attribution 4.0 International License, which permits use, sharing, adaptation, distribution and reproduction in any medium or format, as long as you give appropriate credit to the original author(s) and the source, provide a link to the Creative Commons license, and indicate if changes were made. The images or other third party material in this article are included in the article's Creative Commons license, unless indicated otherwise in a credit line to the material. If material is not included in the article's Creative Commons license and your intended use is not permitted by statutory regulation or exceeds the permitted use, you will need to obtain permission directly from the copyright holder. To view a copy of this license, visit http://creativecommons.org/ licenses/by/4.0/.

(C) The Author(s) 2019 